\title{
Assessment of coastal vulnerability to climate change hazards at the regional scale: the case study of the North Adriatic Sea
}

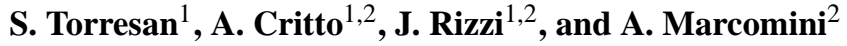 \\ ${ }^{1}$ Centro Euro-Mediterraneo per i Cambiamenti Climatici (CMCC), Impacts on Soil and Coast Division, \\ Via Augusto Imperatore 16, 73100 Lecce, Italy \\ ${ }^{2}$ Department of Environmental Sciences, Informatics and Statistics, University Ca' Foscari Venice, \\ Calle Larga S. Marta 2137, 30123 Venice, Italy
}

Correspondence to: A. Critto (critto@unive.it)

Received: 18 November 2011 - Revised: 10 February 2012 - Accepted: 9 April 2012 - Published: 24 July 2012

\begin{abstract}
Sea level rise, changes in storms and wave climate as a consequence of global climate change are expected to increase the size and magnitude of flooded and eroding coastal areas, thus having profound impacts on coastal communities and ecosystems. River deltas, beaches, estuaries and lagoons are considered particularly vulnerable to the adverse effects of climate change, which should be studied at the regional/local scale. This paper presents a regional vulnerability assessment (RVA) methodology developed to analyse site-specific spatial information on coastal vulnerability to the envisaged effects of global climate change, and assist coastal communities in operational coastal management and conservation. The main aim of the RVA is to identify key vulnerable receptors (i.e. natural and human ecosystems) in the considered region and localize vulnerable hot spot areas, which could be considered as homogeneous geographic sites for the definition of adaptation strategies. The application of the RVA methodology is based on a heterogeneous subset of bio-geophysical and socio-economic vulnerability indicators (e.g. coastal topography, geomorphology, presence and distribution of vegetation cover, location of artificial protection), which are a measure of the potential harm from a range of climate-related impacts (e.g. sea level rise inundation, storm surge flooding, coastal erosion). Based on a system of numerical weights and scores, the RVA provides relative vulnerability maps that allow to prioritize more vulnerable areas and targets of different climate-related impacts in the examined region and to support the identification of suitable areas for human settlements, infrastructures and economic activities, providing a basis for coastal zoning and land use planning. The implementation, performance and results of the methodology for the coastal area of the North Adriatic Sea (Italy) are fully described in the paper.
\end{abstract}

\section{Introduction}

Coastal zones are considered key climate change hot spots worldwide (IPCC, 2007a; Voice et al., 2006; EEA, 2010). The major expected impacts are associated with permanent inundation of low-lying areas, increased flooding due to extreme weather events (e.g. storm surges), and greater erosion rates affecting beaches and cliffs (Nicholls and Cazenave, 2010; EC, 2005; EEA, 2006; Klein et al., 2003). Furthermore, it is widely recognized that climate change can have far reaching consequences on coastal surfaces and groundwater (e.g. saltwater intrusion), coastal ecosystems (e.g. wetlands and biodiversity loss), marine biological communities and commercial species (Abuhoda and Woodroffe, 2006; Wachenfeld et al, 2007; Nicholls, 2004; IPCC, 2008).

At international level two main research communities are involved in the analysis of climate change and climate variability impacts on coastal zones: the natural hazard and the climate change communities.

According to the framework proposed by the natural hazard community (UN-ISDR, 2009), the analysis of the likely impacts or risks related to coastal hazards involves the evaluation of two main components: hazard (i.e. an event or phenomenon with the potential to cause harm, such as loss of life, social and economic damage or environmental degradation) and the system vulnerability (i.e. the characteristics of a system that increase its susceptibility to the impact of climate-induced hazards). In this context, vulnerability is often expressed in a number of quantitative indexes, and is a key step toward risk assessment and management (Romieu et al., 2010).

Within the climate change community, vulnerability is mainly defined as a function of three components: exposure 
(i.e. the magnitude and rate of climate variations, to which a system is exposed), sensitivity (i.e. the degree to which a system could be affected by climate-related stimuli), and adaptive capacity (i.e. the ability of a system to adjust or to cope with climate change consequences) (IPCC, 2007a). According to this framework, the potential consequences of climate change on natural and human systems can be quantified in terms of potential or residual impacts and risks, depending on the consideration of the adaptive capacity component in the final assessment (Füssel and Klein, 2002).

Climate change vulnerability is also defined as a combination of physical, environmental, social and economical factors, whose assessment implies the integration of multiple quantitative and qualitative data (Füssel and Klein, 2006). Moreover, it is considered as a descriptor of the status of a system or community with respect to an imposed hazard (Kienberger et al., 2009) and is related to a given location, sector or group (Hinkel and Klein, 2007).

Considering that climate change impacts and risks on coastal zones are very dependent on regional geographical features, climate and socio-economic conditions, impact studies should be performed at the local or, at most, at the regional level (Torresan et al., 2009).

A relevant challenge is therefore to develop suitable approaches for the assessment of coastal vulnerability to climate-induced hazards at the regional scale, taking into account the best available geographical information for the case study area, in order to highlight most critical regions and support the definition of operational adaptation strategies.

At European level, different tools are suggested to assess coastal vulnerability to climate change at different spatial and temporal scales (Ramieri et al., 2011). They can be categorized into: index-based methods that include several variants of the coastal vulnerability index (CVI; Gornitz, 1990; Gornitz, 1991; Gornitz et al., 1993); GIS-based decision support systems that support decision makers in a sustainable management of natural resources and in the definition of mitigation and adaptation measures (Mocenni et al., 2009; Schirmer et al., 2003); methods based on dynamic computer models that allow to integrate the time dimension in the analysis and mapping of vulnerability and risks of coastal systems to climate change (Hinkel, 2005; Hinkel et al., 2010; Mcleod et al., 2010; Kenny et al., 2000; Warrick et al., 2005; Warrick, 2009; Hsu et al., 2006; Henrotte, 2008; Engelen et al., 1998; Mokrech et al., 2009).

Different tools could be indicated to address coastal vulnerability at different spatial and temporal scales and for different policy and decision-making purposes (Ramieri et al., 2011).

Several indices were developed at the international level for characterising the relative vulnerability of different coasts to sea level rise and coastal erosion impacts (Abuodha and Woodroffe, 2006). These methods would provide a relative measure of the system's vulnerability to the effects of climate change and are designed to make a rapid assessment and visualization of the relative vulnerability of different coastal parcels in the examined area. Index-based tools are particularly useful to make a first assessment of vulnerability of different coastal parcels to climate change, and support adaptation planning and regional integrated coastal zone management (ICZM) strategies.

Generally, index-based methods can be used in different areas and at different spatial scales (e.g. local, regional, supra-regional scale) based on available datasets. Moreover, they are of easy implementation and are based on the analysis of past data (e.g. geomorphic cartography, tide gauge data, land use and socio-economic data), without requiring the use of numerical model projections or of adaptation scenarios.

However, available index-based studies are mostly based on the identification of mono-dimensional shoreline segments (Gornitz, 1990, 1991; Gornitz et al., 1993; Gutierrez et al., 2009). In this way the information about the spatial discontinuity of hazard processes and vulnerable conditions could be obscured, thus misleading policy-related decisions and highlighting unwanted impacts (Kienberger et al., 2009).

Moreover, most of them adopt a single-impact approach that could be useful for the analysis of the consequences associated with individual impacts such as sea level rise (Park et al., 2003; Gutierrez et al., 2009), storm surges (OECD, 2003), and coastal erosion (Colin et al., 2007; Australian Government, 2009; Sharples et al., 2009; McLaughlin and Cooper, 2010), but do not consider the multiple climate change impacts that may affect the same coastal region.

Finally, even if it is widely recommended to adopt an ecosystem perspective in order to represent the complexity of systems, sectors and processes that characterize coastal environments across the land/sea interface (UNEP MAP, 2008), the majority of index-based studies analyse multiple indicators that vary in number and typology, but often refer to individual coastal parcels without considering the geographical distribution of multiple sectors and targets that coexist in the real coastal environment and their specific vulnerability to potential climate change impacts (Gornitz, 1990, 1991; Gornitz et al., 1993; Abuhoda and Woodroffe, 2006; Gutierrez et al., 2009).

The main aim of this paper is therefore to present a methodology for the bi-dimensional assessment and visualization of coastal vulnerability associated with multiple natural and human ecosystems (i.e. beaches, wetlands, protected areas, river mouths, urban and agricultural areas and terrestrial biological systems) and with multiple climate change impacts (i.e. permanent sea level rise inundation, storm surge flooding, coastal erosion). The methodology was developed in order to support regional/subnational assessments and provide suitable information for identifying regions where vulnerability could be relatively high and for planning preventive adaptation measures (e.g. construction of coastal defences, beach nourishment, planning and zoning of coastal territory). The final outcomes of the analysis include the identification and ranking of homogeneous vulnerable units 
for each target of interest, and allow to establish hot spot vulnerable areas and define priorities for intervention. The North Adriatic coastal area was selected to test the regional vulnerability assessment methodology and the main results of the analysis are presented and discussed in this paper.

\section{Case study area}

The Mediterranean Basin is particularly vulnerable to climate changes, which depend on the regional oceanographic responses to global climate change and the local/regional geographical features (Simeoni and Corbau, 2009; EEA, 2006). Particularly, in areas of coastal subsidence, climate-related sea level rise could cause an inland migration of beaches, low-lying and soft sedimentary coasts and significantly increase potential damage from storm surges (Travers et al., 2010). The North Adriatic coast (Fig. 1a) is a representative example of a coastal zone subject to a multitude of significant and rapidly evolving pressures from natural and anthropogenic drivers that are recurrent in the Mediterranean coastline (Simeoni and Corbau, 2009). It holds high ecological, cultural and economic value and includes major centers of population and agriculture.

Specifically, the area considered in this case study comprises Friuli Venezia Giulia and Veneto regions (Fig. 1b) and runs along the Adriatic Sea from the national border between Italy and Slovenia to the mouth of the southern tributary of the Po Delta system (i.e. Po di Goro) with an overall length of about $286 \mathrm{~km}$.

Friuli Venezia Giulia includes three provinces and eight coastal municipalities from the Slovenian border to Tagliamento River mouth. From north-east to south-west, between the Slovenian border and the Timavo River mouth, the coast is high and rocky with few narrow beaches. The overall continuity of the coast is interrupted by several river outlets (e.g. Tagliamento, Isonzo, Timavo) and lagoons (i.e. Marano, Grado). Veneto region includes two provinces and ten coastal municipalities, from Tagliamento to Po River mouth. From north to south, the Veneto coast is characterized by lowlying beaches and by two important lagoons (i.e. Venetian and Po River Delta lagoons). Moreover, it includes the rivers Livenza, Piave, Brenta, Adige and Po that flow into the North Adriatic Sea with an estuary, except for the Po River that flows with a delta, which is the largest wetland area of Europe.

The main coastal activities of the case study area are petrochemical industry, tourism, fishing, seaport/port activities and ship traffic. On the whole, the Northern Adriatic Sea coast comprises a very precarious coastal environment subject to continuous morphological changes that can be appreciable even over short geological time scales (Gambolati and Teatini, 2002). Moreover, erosion is still active in many areas, both on the coastal sea floor and on the beach, since

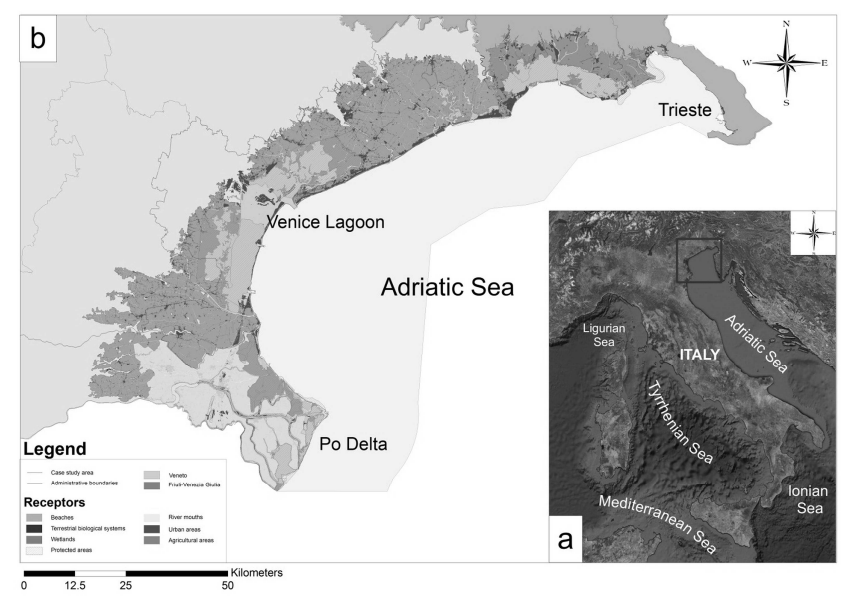

Fig. 1. The case study area: the Northern Adriatic Sea (a) and the coast of the Veneto and Friuli Venezia Giulia regions (Italy) (b). (Adapted from google maps: maps.google.it).

the beginning of the 20th century and especially after 1960 (Bondesan et al., 1995).

Many areas, particularly the Venetian Lagoon and around the Po River Delta, are also located below the mean sea level and affected by natural or man-induced subsidence (Pirazzoli, 2005; Carbognin et al., 2009). Particularly, sites in northeastern Italy are subsiding at rates of $0.5-1 \mathrm{~mm} \mathrm{yr}^{-1}$ with a projection for 2100 at about $135 \mathrm{~mm}$ (Lambeck et al., 2011). Furthermore, the municipality of Venice has been experiencing an increase of high tide events with consequent flooding of the city (Tomasin and Pirazzoli, 2008). Moreover, the historical observations and future projections of isostatic and tectonic movements show that the North Adriatic coast (particularly Venetian, Grado and Marano lagoons) is particularly vulnerable to future sea level rise (Lambeck et al., 2011). Observed sea level rise trends from tide gauge data between 1993 and 2005 showed also a general rise in the Adriatic Sea level, which ranges from 2.9 to $5.7 \mathrm{~cm}$ (Umgiesser et al., 2010). When compared to satellite measurements of the Mediterranean mean $(2.17 \mathrm{~cm})$, the global mean $(3.3 \mathrm{~cm})$ and IPCC data $(3.1 \mathrm{~cm})$, these data indicate that the Adriatic Sea showed a higher rate of sea level rise in the period 1993 to 2005 (Umgiesser et al., 2010).

Therefore, climate change and the related consequences of sea level rise, storminess and coastal erosion are a prominent issue for the case study area, both considering the vulnerability of fragile ecosystems, such as coastal lagoons, and the concentration of cultural and socio-economic values.

Even in recent years when several studies were produced to evaluate potential impacts of storm surge and sea level rise on the coasts of the Northern Adriatic Sea (Bondesan et al., 1995; Gonella et al., 1998; Gambolati and Teatini, 2002; Lionello, 2008), only few significant local sites (e.g. the Venetian Lagoon) were investigated in good detail. Specifically, sectorial studies were conducted in localized areas in order 
to analyze the evolution of the Po River Delta in relation with sea level rise and land subsidence (Simeoni and Corbau, 2009); the relative sea level rise has consequences in the Venetian Lagoon (Carbognin et al., 2009) and the assessment of the potential reduction of aquaculture production in Venetian fisheries due to climate change impacts (Ministry of Environment, 2009). Moreover, wetland deterioration in the Venetian Lagoon was studied in relation to relative sea level rise, erosion by strong waves or low sediment deposition in saltmarshes (Day et al., 1996).

Existing studies were also often targeted to the analysis of specific physical processes (e.g. morphological evolution of deltas and transitional environments in response to sea level rise) without considering other important factors contributing to coastal vulnerability to climate change, such as distribution of coastal assets, inhabitants and ecosystems (Fontolan, 2001; Seminara et al., 2005; Ferla et al., 2007; Simeoni et al., 2007). The complexity of the problems linked to climate change and the importance of considering multiple systems and sectors that interact in the study area ask instead for a broader integrated approach.

The main aim of this paper is therefore to adopt a multidisciplinary approach that takes into account a wide range biogeophysical and socio-economic factors (e.g. altimetry, geomorphology, land use and vegetation cover) in order to analyze the vulnerability of multiple natural and human coastal receptors to several climate change impacts (i.e. sea level rise, storm surge flooding and coastal erosion). Different from a previous approach applied only to the coastal area of the Veneto region and based on the mono-dimensional analysis of shoreline vulnerability to climate change (Torresan et al., 2008), the present work analyses the spatial distribution of coastal vulnerability to climate change in the whole region of the North Adriatic coast, considering the territory included from the shoreline to $2 \mathrm{~m}$ elevation contour line, for a total surface of $3.531 \mathrm{~km}^{2}$.

\section{Methods}

The vulnerability assessment methodology proposed for the estimation of coastal sensitivity to climate change impacts at the regional scale deals with qualitative and quantitative spatial attributes, representing environmental and socioeconomic vulnerability indicators of multiple coastal receptors to climate change. The method is based on a multicriteria decision analysis (MCDA) that includes a wide variety of techniques for the evaluation and ranking of different alternatives, considering all relevant aspects of a decision problem and involving many actors (decision makers as well as experts) (Giove et al., 2009). It integrates expert judgments and stakeholder preferences in order to aggregate quantitative and qualitative environmental and socio-economic indicators, representing the vulnerability of each coastal target to different climate-induced hazards. The application of the methodology allows the identification and prioritization of key vulnerable receptors in the considered region and of homogeneous vulnerable areas, which can be considered as homogeneous geographic sites for the definition of adaptation and management strategies.

The methodology is composed of the following main steps:

1. definition of the regional vulnerability matrix;

2. definition and scoring of vulnerability classes;

3. assignation of weights to vulnerability factors;

4. aggregation of vulnerability factors;

5. normalization and classification of vulnerability values;

6. construction of vulnerability maps.

The following paragraphs describe the application of each step of the methodology for the case study area of the North Adriatic Sea. The results of the application (including vulnerability maps and statistics) are described and discussed in Sect. 4.

\subsection{Definition of the regional vulnerability matrix}

The first step for the implementation of the proposed regional vulnerability assessment methodology is the definition of a regional vulnerability matrix, which identifies multiple coastal receptors that could be affected by multiple climate change impacts. Receptors represent natural or anthropogenic systems of interest within the considered region, due to ecological, economical or social reasons, and are not equally affected by climate change hazards (UKCIP, 2003). For each analyzed receptor, a subset of vulnerability factors representing physical, ecological and socio-economic parameters relevant for the assessment of its vulnerability to different climate change impacts was defined. According to Fig. 2, factors included in the vulnerability matrix are divided into susceptibility factors (SF), pathway factors (PF) and value factors (VF). SF determine the degree to which a receptor could be affected, either adversely or beneficially, by climate-related stimuli. They denote the dose-response relationship between the exposure of a receptor to climate stimuli and the resulting effects. VF identify relevant environmental and socio-economic values of the receptors that need to be preserved for the interest of the community. PF are physical characteristics of the receptors, determining the possibility of contact with climate change hazards and therefore potential exposure areas.

Table 1 shows the vulnerability matrix defined for the North Adriatic case study. It allows the assessment of vulnerability to climate change for eight natural and human receptors (i.e. beaches, river mouths, wetlands, terrestrial biological systems, protected areas, urban and agricultural areas) in relation to the three potential climate-induced impacts (i.e. 


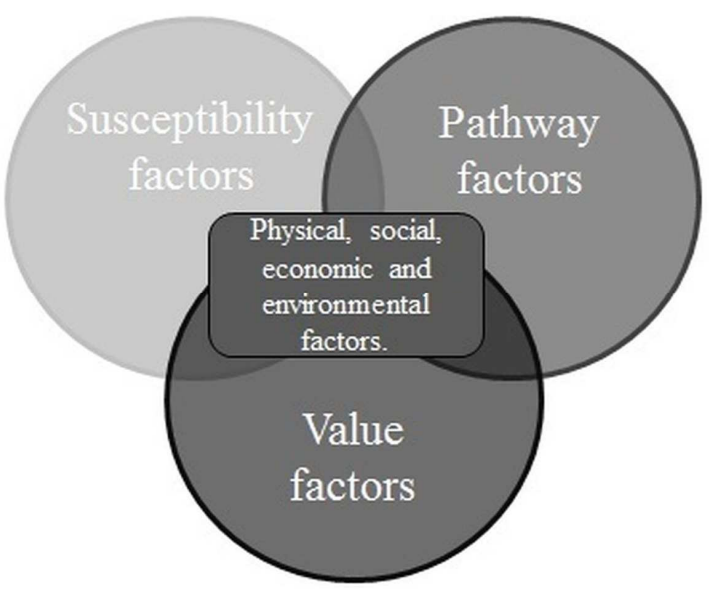

Fig. 2. Conceptualization of vulnerability for the regional vulnerability assessment applied in this paper.

sea level rise inundation, storm surge flooding and coastal erosion). The vulnerability factors included in the matrix are described in Table 2 and the analyzed receptors are defined in Table 3. While the impacts sea level rise inundation and storm surge flooding were considered to be relevant for all the receptors included in the vulnerability matrix (i.e. inland and shoreline receptors), the coastal erosion impact was analyzed only for the receptors that highly interact with shoreline and ocean dynamics (i.e. beaches, river mouths, wetland and protected areas). The selection of vulnerability factors was performed by taking into account the availability of homogeneous GIS data for the whole case study area (Table 4).

\subsection{Definition and scoring of vulnerability classes}

The second step of the methodology consists of the definition of classes and scores for the vulnerability factors (included in the regional vulnerability matrix and reported in Table 2).

The definition of classes and the assignation of scores is a necessary step for the normalization and aggregation of indicators (defined in Sects. 3.3 and 3.4). Susceptibility classes represent thresholds, reflecting variations in the degree to which each receptor may be affected by a climate-related impact; value classes reflect variations in the environmental or socio-economic value associated with each receptor; finally, pathway classes represent variations in the likelihood of contact/exposure of each receptor with each climate change hazard.

Vulnerability classes and scores assigned to the vulnerability factors used in the North Adriatic case are shown in Table 5. Classes are both categorical (e.g. presence or absence of a particular indicator or indicator type) or quantitative (e.g. elevation and slope data). In the first case, classes and scores were assigned by the authors of this paper, representing a team of environmental experts, taking into account literature information when possible or alternatively using expert judgment (Preston et al., 2008). In the second case, classes were mostly derived by dividing the distribution of data into equal-sized sub-ranges (Zald et al., 2006). A non-linear hyperbolic scaling method was used for the factor distance from coastline, assuming that the vulnerability to storm surge increases rapidly with the proximity to the coast. All these classification methods identify relative vulnerability thresholds that are site-specific, and allow the evaluation of the relative coastal vulnerability of different sub-areas in the same region.

According to various methodologies applied at the international level (Gornitz, 1990; Abuodha and Woodroffe, 2006), the assignation of scores to vulnerability classes was performed using a 1-5 scale. For each analyzed impact, this scoring method allowed the definition of relative rankings within the subset of vulnerability classes associated with each vulnerability factor. This means that the maximum score 5 was always assigned to the most important (i.e. higher) vulnerability class and does not represent the maximum vulnerability class in absolute terms (i.e. at the global scale). In the same way the minimum score 1 was assigned to the vulnerability class that was considered the least important (i.e. the lowest vulnerability class) in the subset of classes defined for each indicator. Table 6 provides linguistic evaluations supporting expert(s)/decision maker(s) in the assignation of scores to vulnerability factors. According to Giove et al. (2009), the expert judgments should have a sound scientific and technical basis, while the decision-maker judgments are usually based on more subjective political and managerial considerations. Consequently, the integration of expert judgement is particularly important for the assignation of scores to physical, natural and ecological parameters (i.e. pathway and susceptibility factors) and the role of a decision maker is fundamental in the evaluation of socio-economic parameters (i.e. value factors). Finally, it is important to consider that the integration of expert/decision maker perspective is significantly important in situations of uncertainty and data scarcity, such as environmental risk and vulnerability assessments (Giove et al., 2009).

As shown in Table 5, arbitrary elevation and distance limits were identified for pathway factors (i.e. elevation and distance from coastline) in order to determine the spatial extent of potential areas exposed to sea level rise and storm surge impacts. The selected elevation limit corresponds to $0.6 \mathrm{~m}$ for sea level rise inundation and to $2 \mathrm{~m}$ for storm surge flooding. The first elevation limit was cautiously defined considering the latest IPCC report, assuming $59 \mathrm{~cm}$ as higher sea level rise scenario at the global scale (IPCC, 2007b). However, some recent papers provide higher upper boundaries of global sea level rise projections, based on a deeper analysis of ice dynamics (Pfeffer et al., 2008) or on semi-empirical approaches (Rahmstorf, 2007; Vermeer and Rahmstorf, 2009). The second elevation limit developed for storm surges represents an upper limit associated with the most extreme event observed in the last century in the case study area (i.e. the 
Table 1. Vulnerability matrix applied for the assessment of coastal vulnerability to sea level rise inundation (a), storm surge flooding (b) and coastal erosion (c) in the coastal area of the North Adriatic Sea. Dark grey cells represent pathway factors, grey cells susceptibility factors and light grey cells value factors.

\begin{tabular}{|c|c|c|c|c|c|c|c|}
\hline Receptors Impacts & Beaches & $\begin{array}{l}\text { River } \\
\text { Mouths }\end{array}$ & Wetlands & $\begin{array}{l}\text { Terrestrial } \\
\text { Biological Systems }\end{array}$ & $\begin{array}{l}\text { Protected } \\
\text { Areas }\end{array}$ & $\begin{array}{l}\text { Urban } \\
\text { Areas }\end{array}$ & $\begin{array}{l}\text { Agricultural } \\
\text { Areas }\end{array}$ \\
\hline \multicolumn{8}{|l|}{$\begin{array}{l}\text { Hydrodynamic } \\
\text { IMPACTS }\end{array}$} \\
\hline $\begin{array}{l}\text { Sea level rise } \\
\text { inundation (a) }\end{array}$ & $\begin{array}{l}\text { - Elevation } \\
\text { - Artificial protections } \\
\text { - Protection level }\end{array}$ & $\begin{array}{l}\text { - Elevation } \\
\text { - Artificial protections } \\
\text { - Protection level } \\
\text { - Urban typology } \\
\text { - Agricultural typology }\end{array}$ & $\begin{array}{l}\text { - Elevation } \\
\text { - Artificial protections } \\
\text { - Protection level } \\
\text { - Wetland extension }\end{array}$ & $\begin{array}{l}\text { - Elevation } \\
\text { - Artificial protections } \\
\text { - Protection level } \\
\text { - Vegetation cover }\end{array}$ & $\begin{array}{l}\text { - Elevation } \\
\text { - Artificial protections } \\
\text { - Protection level } \\
\text { - Urban typology } \\
\text { - Agricultural typology }\end{array}$ & $\begin{array}{l}\text { - Elevation } \\
\text { - Artificial protections } \\
\text { - Protection level } \\
\text { - Urban typology }\end{array}$ & $\begin{array}{l}\text { - Elevation } \\
\text { - Artificial protections } \\
\text { - Protection level } \\
\text { - Agricultural typology }\end{array}$ \\
\hline Storm surge flooding (b) & $\begin{array}{l}\text { - Elevation } \\
\text { - Distance from coastline } \\
\text { - Artificial protections } \\
\text { - Vegetation cover } \\
\text { - Coastal slope } \\
\text { - Geomorphology } \\
\text { - Dunes } \\
\text { - Protection level }\end{array}$ & $\begin{array}{l}\text { - Elevation } \\
\text { - Distance from coastline } \\
\text { - Artificial protections } \\
\text { - Vegetation cover } \\
\text { - Coastal slope } \\
\text { - Geomorphology } \\
\text { - Protection level } \\
\text { - Urban typology } \\
\text { - Agricultural typology }\end{array}$ & $\begin{array}{l}\text { - Elevation } \\
\text { - Distance from coastline } \\
\text { - Artificial protections } \\
\text { - Vegetation cover } \\
\text { - Wetland extension } \\
\text { - Protection level }\end{array}$ & $\begin{array}{l}\text { - Elevation } \\
\text { - Distance from coastline } \\
\text { - Vegetation cover } \\
\text { - Coastal slope } \\
\text { - Protection level } \\
\text { - Vegetation cover }\end{array}$ & $\begin{array}{l}\text { - Elevation } \\
\text { - Distance from coastline } \\
\text { - Artificial protections } \\
\text { - Vegetation cover } \\
\text { - Coastal slope } \\
\text { - Protection level } \\
\text { - Urban typology } \\
\text { - Agricultural typology }\end{array}$ & $\begin{array}{l}\text { - Elevation } \\
\text { - Distance from coastline } \\
\text { - Artificial protections } \\
\text { - Coastal slope } \\
\text { - Urban typology } \\
\text { - Protection level } \\
\text { - Urban typology }\end{array}$ & $\begin{array}{l}\text { - Elevation } \\
\text { - Distance from coastline } \\
\text { - Artificial protections } \\
\text { - Coastal slope } \\
\text { - Agricultural typology } \\
\text { - Protection level } \\
\text { - Agricultural typology }\end{array}$ \\
\hline Coastal erosion (c) & $\begin{array}{l}\text { - Artificial protections } \\
\text { - Vegetation cover } \\
\text { - Coastal slope } \\
\text { - Geomorphology } \\
\text { - Dunes } \\
\text { - Sediment budget } \\
\text { - Protection level }\end{array}$ & $\begin{array}{l}\text { - Artificial protections } \\
\text { - Vegetation cover } \\
\text { - Geomorphology } \\
\text { - Sediment budget } \\
\text { - Mouth typology } \\
\text { - Protection level }\end{array}$ & $\begin{array}{l}\text { - Artificial protections } \\
\text { - Vegetation cover } \\
\text { - Sediment budget } \\
\text { - Wetland extension } \\
\text { - Protection level }\end{array}$ & & $\begin{array}{l}\text { - Artificial protections } \\
\text { - Vegetation cover } \\
\text { - Sediment budget } \\
\text { - Protection level }\end{array}$ & & \\
\hline
\end{tabular}

Table 2. Vulnerability factors used for the assessment of coastal vulnerability to climate change at the regional scale in the coastal area of the North Adriatic Sea. Vulnerability factors are categorized into pathway factors (P), susceptibility factors (S), and value factors (V).

\begin{tabular}{|c|c|c|}
\hline Vulnerability factor & $\begin{array}{l}\text { Vulnerability } \\
\text { type }\end{array}$ & Definition \\
\hline Elevation & $\mathrm{P}$ & $\begin{array}{l}\text { It represents the surface }\left(\mathrm{km}^{2}\right) \text { within a class of elevation } \mathrm{X}_{i}\left(\text { e.g. } 0.15 \mathrm{~m} \leq \mathrm{X}_{i} \leq 0.3 \mathrm{~m}\right) \\
\text { in the case study area. }\end{array}$ \\
\hline Distance from coastline & $\mathrm{P}$ & The distance of a location (e.g. a pixel of the map) from the coastline $(\mathrm{km})$. \\
\hline Artificial protection & $\mathrm{S}$ & $\begin{array}{l}\text { Artificial protections (e.g. dikes) for the defence of the coastline from storm surge and } \\
\text { coastal erosion impacts. }\end{array}$ \\
\hline Vegetation cover & $\mathrm{S}$ & $\begin{array}{l}\text { The typology of vegetation that cover an area (i.e. natural grassland and meadow, shrub, } \\
\text { forest). }\end{array}$ \\
\hline Coastal slope & $\mathrm{S}$ & Average topographic slope (in degrees) along the coastline. \\
\hline Geomorphology & $\mathrm{S}$ & $\begin{array}{l}\text { Geomorphologic structure of the coastal zone. It refers to muddy, sandy or rocky coast } \\
\text { typology. }\end{array}$ \\
\hline Dunes & $\mathrm{S}$ & It refers to the presence or absence of natural dunes. \\
\hline Sediment budget & $\mathrm{S}$ & $\begin{array}{l}\text { The balance between the supply of sediment (e.g. sand) to a shore and the erosion or } \\
\text { removal of sediment from that shore. }\end{array}$ \\
\hline Mouth typology & $\mathrm{S}$ & It refers to the type of river mouths (i.e. estuary, delta). \\
\hline Wetland extension & $\mathrm{S} / \mathrm{V}$ & The surface area of wetlands in square kilometres $\left(\mathrm{km}^{2}\right)$. \\
\hline Urban typology & $\mathrm{S} / \mathrm{V}$ & The typology of urban areas (i.e. urban fabric, commercial fabric, infrastructure). \\
\hline Agricultural typology & $\mathrm{S} / \mathrm{V}$ & The typology of farming in an area (i.e. permanent crops, pastures and arable land). \\
\hline Protection level & $\mathrm{V}$ & $\begin{array}{l}\text { It refers to the type of protected areas within the considered receptor (i.e. national area, } \\
\text { regional area, Natura } 2000 \text { area). }\end{array}$ \\
\hline
\end{tabular}


Table 3. Description of the receptors included in the vulnerability matrix and identified as targets of the regional vulnerability assessment methodology applied to the North Adriatic coast.

\begin{tabular}{|c|c|}
\hline Receptor & definition \\
\hline Beaches & $\begin{array}{l}\text { This receptor analyzes beaches and the vegetation associated with them. Furthermore, it analyzes natural and ar- } \\
\text { tificial protections to climatic impacts. Sandy coastal areas are important for tourism, recreation and residential } \\
\text { development (Voice et al., 2006). Sand-grade sediments are generally defined to be those predominantly composed } \\
\text { of grains ranging between } 0.06 \text { to } 2.0 \mathrm{~mm} \text { diameter (Pettijohn, 1973). In the coastal environment, unconsolidated } \\
\text { sediments within this grain size range are highly mobile and small enough to be easily eroded and transported } \\
\text { by waves, currents and winds that frequently act on most shorelines, in contrast to larger (pebble/cobble/boulder) } \\
\text { particles that are moved by very energetic waves and hardly at all by wind (Sharples, 2006). }\end{array}$ \\
\hline River mouth & $\begin{array}{l}\text { This receptor includes estuaries and deltas. Estuaries are important receptors because they contain significant habi- } \\
\text { tats including seagrasses, mudflats/sandflats, saltmarshes, reed, sedge and rush communities, and provide sheltered } \\
\text { habitat, nursery and spawning areas for fish, crabs, prawns and shellfish (Voice et al., 2006). Delta is a landform } \\
\text { where the mouth of a river flows into the sea. It builds up sediment outwards into the flat area, which the river flow } \\
\text { encounters (as a deltaic deposit), transported by the water and set down as the currents slow. Deltas present high } \\
\text { biodiversity and significant habitats (wetlands). }\end{array}$ \\
\hline Wetlands & $\begin{array}{l}\text { The wetland receptor includes coastal wetlands along with vegetation, animal life and artificial and natural protec- } \\
\text { tions located in wetlands areas. A wetland is an environment at the interface between truly terrestrial ecosystems and } \\
\text { aquatic systems, making them inherently different from each other yet highly dependent on both (Mitsch, 2007). }\end{array}$ \\
\hline $\begin{array}{l}\text { Terrestrial } \\
\text { biological } \\
\text { systems }\end{array}$ & $\begin{array}{l}\text { This receptor includes animal and plant terrestrial life, their habitats and the ecological functions they provide. } \\
\text { Specifically, terrestrial biodiversity encompasses the total variety of life forms including plants, animals and micro- } \\
\text { organisms and the processes and ecosystems they form (EPA, 2002). }\end{array}$ \\
\hline Protected areas & $\begin{array}{l}\text { A protected area is defined as an area of land and/or sea especially dedicated to the protection and maintenance } \\
\text { of biological diversity and of natural and associated cultural resources, managed through legal or other effective } \\
\text { means (UNEP-WCMC, http://www.unep-wcmc.org/protected_areas/index.htm). } \\
\text { This receptor include areas with biological, morphological or historical sensitive aspects. An example of protected } \\
\text { areas include wetlands, marine areas, national parks, and national heritage. They provide tourism income, fisheries } \\
\text { breeding and spawning grounds, ecosystem protection and protection of historical locations (Voice et al., 2006). }\end{array}$ \\
\hline Urban areas & $\begin{array}{l}\text { This receptor includes areas cover by countries, residential areas, commercial zones and industries. It includes } \\
\text { areas in which a majority of the people are not directly dependent on natural resource-based occupations (http: } \\
\text { //www.mhhe.com/biosci/pae/glossaryu.html). Specifically, it includes areas mainly occupied by dwellings and } \\
\text { buildings used by administrative/public utilities or collectivities, including their connected areas: areas mainly oc- } \\
\text { cupied by industrial activities of transformation and manufacturing, trade, financial activities and services, transport } \\
\text { infrastructures for road traffic and rail networks, airport installations, river and sea port installations, including their } \\
\text { associated lands and access infrastructures, and areas voluntarily created for recreational use (Bossard et al., 2000). }\end{array}$ \\
\hline $\begin{array}{l}\text { Agricultural } \\
\text { areas }\end{array}$ & $\begin{array}{l}\text { This receptor includes areas comprised of arable land, gardens and other perennial plants, meadows and natural } \\
\text { pastures (http://regionai.stat.gov.lt/en/savokos.html\#Agricultural\%20land). It includes arable land (lands under a } \\
\text { rotation system used for annually harvested plants and fallow lands, which are permanently or not irrigated), per- } \\
\text { manent crops (all surfaces occupied by permanent crops, not under a rotation system), pastures (lands that are } \\
\text { permanently used for fodder production) (Bossard et al., 2000). }\end{array}$ \\
\hline
\end{tabular}

water level reached by the storm surge event happened in Venice on 4 November 1966). Finally, the distance limit defined for the storm surge flooding impact (i.e. $52.62 \mathrm{~km}$ ) was determined according to the maximum distance inland reached by the $2 \mathrm{~m}$ contour line. The upper limits defined for pathway factors allowed to delimitate the study area only to areas associated with a plausible exposure to coastal hazards (Preston, 2008). Accordingly, all others vulnerability factors and their qualitative and quantitative scoring were focused on this area.
According to Kienberger et al. (2009), the selection and scoring of categorical classes were performed with the help of expert knowledge, considering data availability and coverage. Moreover, the assignation of scores to the same categorical vulnerability factors can vary from one impact to another.

As shown in Table 5, geomorphology, sediment budget and mouth typology were considered as key factors determining coastal susceptibility to coastal erosion. Considering that the potential susceptibility to coastal erosion increases for finer and unconsolidated sediments, the lower 
Table 4. Datasets used for the application of the regional vulnerability assessment methodology to the case study area (i.e. the North Adriatic coasts $).$ FVG $=$ Friuli Venezia Giulia region, Italy. VE = Veneto region, Italy. ISPRA = High Institute for Environmental Protection and Research, Italy. ESRI = Environmental Systems Research Institute.

\begin{tabular}{|c|c|c|}
\hline Dataset & Spatial domain & Source \\
\hline Contour lines 1:5000 & FVG & FVG, 2006 \\
\hline $\begin{array}{l}25 \mathrm{~m} \text { digital elevation model } \\
(\mathrm{DEM})\end{array}$ & VE, FVG & VE, 2006 \\
\hline $\begin{array}{l}\text { Hydrologic basins: rivers and } \\
\text { channels } 1: 25000\end{array}$ & FVG & FVG 2000 \\
\hline Corine Land Cover, 1:100 000 & $\begin{array}{l}\text { FVG } \\
\text { VE }\end{array}$ & $\begin{array}{l}\text { FVG, ISPRA, } 2000 \\
\text { VE, } 2000\end{array}$ \\
\hline Land use, 1:25000 & FVG & FVG, 2000 \\
\hline $\begin{array}{l}\text { Protected areas and ARIA } \\
\text { zones, 1:150000 }\end{array}$ & FVG & $\mathrm{FVG}^{\mathrm{a}} 2000$ \\
\hline $\begin{array}{l}\text { Geographic aoastal } \\
\text { information system } \\
\text { (SIGC) }\end{array}$ & Italy & $\begin{array}{l}\text { ISPRA, www.mais.sinanet.apat.it/cartanetms/ } \\
\text { coste/ }\end{array}$ \\
\hline $\begin{array}{l}\text { Geologic and geomorphologi- } \\
\text { cal map of the Po River Delta, } \\
\text { 1:50000 }\end{array}$ & Po River Delta & Veneto Po Delta Regional Park Authority, 2002 \\
\hline Map of roads & North Adriatic & $\begin{array}{l}\text { ESRI, www.esri.com/data/download/basemap/ } \\
\text { index.html }\end{array}$ \\
\hline Main cities & FVG & FVG, 2006 \\
\hline $\begin{array}{l}\text { Buildings (houses, industries, } \\
\text { etc.) }\end{array}$ & FVG & FVG, 2006 \\
\hline Administrative unit boundaries & $\begin{array}{l}\text { VE } \\
\text { FVG }\end{array}$ & $\begin{array}{l}\text { VE, } 2005 \\
\text { FVG, } 2006\end{array}$ \\
\hline Location of primary rivers & $\begin{array}{l}\text { VE } \\
\text { FVG }\end{array}$ & $\begin{array}{l}\text { ISPRA, www.mais.sinanet.apat.it/cartanetms/ } \\
\text { FVG, } 2000\end{array}$ \\
\hline Satellite imagery & North Adriatic & http://image2000.jrc.it/ \\
\hline
\end{tabular}

score was assigned to hard rocky coasts, an intermediate score was assigned to soft sandy shores and the higher score to finer muddy shores (e.g. mainly estuarine and deltaic) (Sharples, 2006). Concerning historic shoreline erosion rates, the higher vulnerability score was attributed to retreating coasts, compared to stable and prograding ones (Torresan, 2008; Abuodha and Woodroffe, 2006). Finally, fluvial deltaic areas were considered less vulnerable than estuarine ones to eroding processes (Sharples, 2006).

The presence of artificial protection was considered a relevant factor decreasing susceptibility of the coastline to coastal erosion and storm surge flooding (Özyurt, 2008). Accordingly, the maximum vulnerability score (i.e. 5) was assigned to coastal parcels without artificial protections and the minimum score (i.e. 1) to coastal units with engineered frontage. In the same way the presence of natural dunes was considered as a factor reducing the susceptibility of soft sandy shores to storm surge and coastal erosion, compared to the absence (McLaughlin and Cooper, 2010).

With respect to ecological parameters, wetland extension and vegetation cover, they were also considered as relevant susceptibility factors for storm surge flooding and coastal erosion. For the first parameter the higher susceptibility scores were assigned to coastal wetlands with lower surface area, which may be more sensitive to coastal erosion and storm surge pressures than wider ones (Torresan et al., 2008). For the latter parameter, it was considered that coastal erosion and storm surge susceptibility is increased if the soil has no or very little vegetative cover of plants (Preston et al., 2008; ARC, 2000). Moreover, for the agricultural typology indicator in relation to the storm surge flooding impact, higher susceptibility scores were assigned to arable land (i.e. land under a rotation system or fallow land) that has a lower protective cover than other identified classes (French, 2001). 
Table 5. Classes and scores applied to vulnerability factors used in the North Adriatic in order to estimate the vulnerability of coastal receptors to the following climate change impacts: sea level rise inundation (SLR); storm surge flooding (SSF); coastal erosion (CE). Scores refer to pathway factors (dark grey cells), susceptibility factors (grey cells) and value factors (light grey cells).

\begin{tabular}{|c|c|c|c|c|c|}
\hline \multirow[b]{2}{*}{ Vulnerability Factor } & \multicolumn{2}{|c|}{ Class } & \multicolumn{3}{|c|}{ Score } \\
\hline & SLR & SSF & SLR & SSF & $\mathrm{CE}$ \\
\hline \multirow[t]{5}{*}{ Elevation (m) } & $\operatorname{Min}-0$ & $\operatorname{Min}-0$ & 5 & 5 & \\
\hline & $0-0.15$ & $0-0.5$ & 4 & 4 & \\
\hline & $0.15-0.3$ & $0.5-1$ & 3 & 3 & \\
\hline & $0.3-0.45$ & $1-1.5$ & 2 & 2 & \\
\hline & $0.45-0.6$ & $1.5-2$ & 1 & 1 & \\
\hline \multirow[t]{6}{*}{ Distance from coastline $(\mathrm{km})$} & \multirow{5}{*}{\multicolumn{2}{|c|}{$\begin{array}{c}0-3.29 \\
3.29-6.58 \\
6.58-13.16 \\
13.16-26.31 \\
26.31-52.62\end{array}$}} & & 5 & \\
\hline & & & & 4 & \\
\hline & & & & 3 & \\
\hline & & & & 2 & \\
\hline & & & & 1 & \\
\hline & SSF & $\mathrm{CE}$ & & & \\
\hline \multirow[t]{5}{*}{ Coastal slope (degree) } & $0-2.06$ & $060-1.02$ & & 5 & 1 \\
\hline & $2.06-4.12$ & $1.02-2.04$ & & 4 & 2 \\
\hline & $4.12-6.18$ & $2.04-3.07$ & & 3 & 3 \\
\hline & $6.18-8.24$ & $3.07-4.09$ & & 2 & 4 \\
\hline & $8.24-10.31$ & $4.09-5.12$ & & 1 & 5 \\
\hline \multirow[t]{3}{*}{ Geomorphology } & \multirow{3}{*}{\multicolumn{2}{|c|}{$\begin{array}{l}\text { Muddy coast } \\
\text { Sandy coast } \\
\text { Rocky coast }\end{array}$}} & & & 5 \\
\hline & & & & & 3 \\
\hline & & & & & 1 \\
\hline \multirow[t]{2}{*}{ Artificial protections } & \multirow{2}{*}{\multicolumn{2}{|c|}{$\begin{array}{l}\text { absence } \\
\text { presence }\end{array}$}} & & 5 & 5 \\
\hline & & & & 1 & 1 \\
\hline \multirow[t]{3}{*}{ Sediment budget } & \multirow{3}{*}{\multicolumn{2}{|c|}{$\begin{array}{l}\text { Prograding coast } \\
\text { Stable coast } \\
\text { Retreating coast }\end{array}$}} & & & 1 \\
\hline & & & & & 3 \\
\hline & & & & & 5 \\
\hline \multirow[t]{5}{*}{ Wetland extension $\left(\mathrm{km}^{2}\right)$} & \multicolumn{2}{|c|}{$0-19.9$} & 1 & 5 & 5 \\
\hline & \multicolumn{2}{|c|}{$19.9-39.8$} & 2 & 4 & 4 \\
\hline & \multicolumn{2}{|c|}{$39.8-59.8$} & 3 & 3 & 3 \\
\hline & \multicolumn{2}{|c|}{$59.8-79.7$} & 4 & 2 & 2 \\
\hline & \multicolumn{2}{|c|}{$79.7-99.6$} & 5 & 1 & 1 \\
\hline \multirow[t]{3}{*}{ Vegetation cover } & \multirow{3}{*}{\multicolumn{2}{|c|}{$\begin{array}{c}\text { Natural grassland and meadow } \\
\text { Shrub } \\
\text { Forest }\end{array}$}} & 1 & 5 & 5 \\
\hline & & & 3 & 3 & 3 \\
\hline & & & 5 & 1 & 1 \\
\hline \multirow[t]{3}{*}{ Protection level } & \multicolumn{2}{|c|}{ National area } & 5 & 5 & 5 \\
\hline & Reg & al area & 3 & 3 & 3 \\
\hline & Natu & 000 area & 1 & 1 & 1 \\
\hline Mouth typology & & $\operatorname{ary}$ & & & 5 \\
\hline & & & & & 1 \\
\hline Dunes & & ence & & 1 & 1 \\
\hline & & ence & & 5 & 5 \\
\hline Urban typology & $\mathrm{Ur}$ & fabric & 5 & 1 & \\
\hline & Comn & ial fabric & 3 & 3 & \\
\hline & $\operatorname{Inft}$ & ucture & 1 & 5 & \\
\hline Agricultural typology & Perm & nt crops & 5 & 1 & \\
\hline & & ares & 1 & 3 & \\
\hline & & land & 3 & 5 & \\
\hline
\end{tabular}


Table 6. Linguistic evaluations supporting the expert/decision maker in the assignation of scores to vulnerability factors.

\begin{tabular}{lc}
\hline Linguistic Evaluation & Score \\
\hline Most important class & 5 \\
Weakly less important class & 4 \\
Rather less important class & 3 \\
Strongly less important class & 2 \\
Least important class & 1 \\
\hline
\end{tabular}

As far as value factors are concerned, the protection level was considered a relevant parameter for all the impacts. In particular, according to McLaughlin and Cooper(2010), higher scores were assigned to national conservation designation and lower scores to international ones.

Urban and agricultural typology, vegetation cover and wetland extension were also considered as key value factors for the sea level rise impact. Concerning urban/agricultural typology and vegetation cover, higher value scores were assigned to classes showing higher environmental and socioeconomic value, such as urban fabric, permanent crops and forests, respectively (Preston, 2008; McLaughlin and Cooper, 2010; Torresan, 2008). Finally, for the wetland extension indicator, the higher value scores were assigned to wider wetlands considered as priority values to be protected compared to smaller ones.

\subsection{Assignation of weights to vulnerability factors}

The proposed methodology for the assessment of coastal vulnerability to climate change impacts combines information from several indicators in order to create a vulnerability index associated with single receptors. Accordingly, the process used to generate the final vulnerability index requires (1) the aggregation of single vulnerability factors within each of the three vulnerability domains (i.e. susceptibility, pathway and value)and (2) the aggregation of vulnerability domains in the final vulnerability index.

Individual vulnerability factors can be weighted to represent the relative importance of each indicator in each vulnerability domain. A total weight can also be assigned to each vulnerability domain in order to represent its relative importance in the final estimate of receptor vulnerability.

The allocation of weights is a critical issue since datasets on verification of impacts are not yet available for multidisciplinary approaches (Kienberger et al., 2009). However, MCDA methodologies are commonly used to integrate expert and decision-maker knowledge in scoring and weighting exercises (Cutter et al., 2008; Malczewski, 2006).

A guideline with linguistic evaluations supporting expert(s) and decision maker(s) in the assignation of weights to vulnerability factors and vulnerability domains is proposed in Table 7.
Table 7. Linguistic evaluations supporting the expert/decision maker in the assignation of weights to vulnerability factors and vulnerability domains.

\begin{tabular}{lc}
\hline Linguistic Evaluation & Weight \\
\hline Most important vulnerability factor/domain & 1 \\
Weakly less important vulnerability factor/domain & 0.75 \\
Strongly less important vulnerability factor/domain & 0.5 \\
Demonstratively less important vulnerability factor/domain & 0.25 \\
Not important vulnerability factor/domain & 0 \\
\hline
\end{tabular}

Vulnerability factors(domains) judged to have higher influence on vulnerability domain(index) were assigned a weight of 1 ; on the other side, vulnerability factors(domains) judged to have no influence on the final vulnerability domain(index) were assigned a weight of 0 .

While weights related to susceptibility and pathway components are generally assigned by an interdisciplinary team of experts, weights assigned to value components often require the judgment of decision-makers, which can be more oriented in safeguarding the environment (e.g. giving higher weights to the susceptibility domain or to ecological criteria, such as protection level and vegetation value) or in preserving the human exploitation of land use (i.e. assigning higher weights to the value domain or to urban and agricultural economic values). Group decision theory techniques (Kiker et al., 2005) could be applied in order to facilitate involvement, preference elicitation and consensus evaluation of experts and decision-makers working as a decision group.

For this case study it was assumed that susceptibility, pathway, and value domains should have the same importance in determining the receptor vulnerability to each climate change impact. Moreover, it was assumed that all the vulnerability factors attain the same weight within each vulnerability domain. Accordingly, the same weight equal to 1 was assigned by default, both to vulnerability domains and to vulnerability factors.

\subsection{Aggregation of vulnerability factors}

According to the conceptual vulnerability framework adopted in this paper, vulnerability is a multi-dimensional concept, encompassing physical, social, economic, and environmental factors (Fig. 2) that may contribute in determining the sensitivity of a natural or human coastal receptor to different climate change impacts (i.e. sea level rise, storm surge flooding, coastal erosion).

In more detail, the assessment of receptor vulnerability to climate change is based on the analysis of multiple geographical indicators that are first aggregated in three vulnerability domains (i.e. susceptibility, value and pathway) and then in the final vulnerability index.

In order to integrate different susceptibility, pathway and value factors into each vulnerability domain and then to es- 
timate the final vulnerability index for each receptor $j$ in relation to each considered impact $k$, a weighted linear combination was used according to the following equation:

$$
\begin{gathered}
V_{j, k}=W_{A} \frac{\sum_{a=1}^{n} w_{a, k, j} \mathrm{SF}_{a, k, j}}{\sum_{a=1}^{n} w_{a, k, j}}+W_{B} \frac{\sum_{b=1}^{m} w_{b, k, j} \mathrm{PF}_{b, k, j}}{\sum_{b=1}^{m} w_{b, k, j}}+ \\
+W_{C} \frac{\sum_{c=1}^{p} w_{c, k, j} \mathrm{VF}_{c, k, j}}{\sum_{c=1}^{p} w_{c, k, j}}
\end{gathered}
$$

where $V_{j, k}=$ vulnerability index related to the receptor $j$ and the impact $k . \mathrm{SF}_{a, k, j}=$ score related to the susceptibility factor $a$, the receptor $j$ and the impact $k . \mathrm{PF}_{b, k, j}=$ score related to the pathway factor $b$, the receptor $j$ and the impact $k . \mathrm{VF}_{c, k, j}=$ score related to the value factor $c$, the receptor $j$ and the impact $k . w_{a, k, j}=$ weight associated with the $a$ susceptibility factor for the receptor $j$ and the impact $k . w_{b, k, j}$ $=$ weight associated with the $b$ pathway factor for the receptor $j$ and the impact $k . w_{c, k, j}=$ weight associated with the $c$ value factor for the receptor $j$ and the impact $k . W_{A}=$ weight associated with the susceptibility domain. $W_{B}=$ weight associated with the pathway domain. $W_{C}=$ weight associated with the value domain. $n=$ total number of susceptibility factors. $m=$ total number of pathway factors. $p=$ total number of value factors.

Equation (1) is a typical multi-attribute value theory (MAVT) aggregation function. MAVT is a particular family of multi-criteria decision analysis methods that combines information from several criteria along with expert judgment in order to estimate single indexes (Malczewski, 2006; Giove et al., 2009).

While the scores used in the assessment of the vulnerability index are derived from Table 5, the weights were calculated according to Sect. 3.3.

The function proposed to calculate the vulnerability index (Eq. 1) is applied within each receptor in all the spatial units of the analysis (i.e. each pixel of the used raster maps). The dimension of the grid cells should be selected at the beginning of the assessment, based on the purposes of the analysis and on the spatial resolution of available data. For this case study the analysis was done based on $25 \mathrm{~m}$ cells that correspond to the spatial resolution of the topographic dataset, available in a single unified format for the coasts of Veneto and Friuli Venezia Giulia regions (Table 4). According to Shuang-Ye et al. (2009) and Torresan et al. (2008), this can be a suitable resolution to make estimates at the national and sub-national scales and quantify the impacts of climate change on natural and human receptors.

\subsection{Normalization and classification of vulnerability values}

In order to convert all the vulnerability indexes in the same standard scale ranging from 1 to 10 and facilitate the comparative analysis of vulnerability values in the case study area, a normalization procedure should be performed. For the application of the regional vulnerability assessment on the North Adriatic coast, all the vulnerability values obtained from Eq. (1) were converted in the range between 1 and 10 according to the following linear equation:

$V_{j, k}^{\prime}=(10-1) \times \frac{V_{j, k}-V_{j, k(\min )}}{V_{j, k(\max )}-V_{j, k(\min )}}+1$

where $V_{j, k}^{\prime}=$ normalized vulnerability index related to the receptor $j$ and the impact $k ; V_{j, k}=$ initial vulnerability index; $V_{j, k(\max )}=$ maximum vulnerability value obtained for the receptor $j$ and the impact $k ; V_{j, k(\min )}=$ minimum vulnerability value obtained for the receptor $j$ and the impact $k$.

The normalization procedure allows a more clear relative comparison of vulnerability values related to different vulnerable receptors for the same climate change impact.

Normalized vulnerability values vary from 1 to 10 and allow to establish homogeneous vulnerable areas for each receptor considered in the region. $V_{j, k}^{\prime}$ equal to 1 means that a grid cell has the lower vulnerability value that could be assumed in relation to a given receptor $j$ and impact $k$. In the same way, $V_{j, k}^{\prime}$ equal to 10 means that a cell has higher vulnerability value that could be assumed for the receptor $j$ and the impact $k$.

In order to allow a clear visualization of the vulnerability index into vulnerability maps (Sect. 3.6), the vulnerability values ranging from 1 to 10 were categorized into 5 qualitative subclasses (i.e. very high, high, medium, low and very low). The five classes were accomplished by dividing the vulnerability range $V_{j, k(\max )}-V_{j, k(\min )}$ into five equal-sized sub-ranges (Zald et al., 2006). Equal interval classification is useful when the objective of the spatial analysis is to emphasize the amount of an attribute value relative to another value. For this aim, the equal interval was selected as an appropriate GIS method in order to compare vulnerability between different sub-areas included in wider coastal system.

For each analyzed receptor, the very high classes identify sub-areas characterized by higher vulnerability values in the considered region and therefore are more likely to be affected by a single climate change impact.

The proposed vulnerability index provides information about the relative vulnerability of areas and receptors within a region in relation to potential climate change impacts. It does not provide information about the absolute vulnerability of a given area or receptor; rather, it produces a vulnerabilitybased ranking of the assessed areas and receptors. This implies that results related to different impacts cannot be compared. 


\subsection{Construction of vulnerability maps}

The main output of the methodology developed to study climate change coastal vulnerability at the regional scale includes GIS-based vulnerability maps that represent the spatial variability of the vulnerability index (described in Sects. 3.4 and 3.5).

For each considered impact, vulnerability maps allow the visualization and prioritization of coastal receptor units according to values assumed by the vulnerability index (Eq. 2). In this way it is possible to identify more sensitive areas and receptors in the coastal territory (i.e. hot spot vulnerable areas), and transfer information to stakeholders and decision makers in order to support them in the planning of appropriate adaptation measures.

The diversity of reference systems, formats, and spatial resolutions required several pre-processing elaborations in order to homogenise the used dataset. A spatially homogenous data scale of a $25 \mathrm{~m}$ grid was used for the elaboration on the North Adriatic coast. The base map to which all maps were homogenised is the digital elevation model (DEM). This represented the most adequate scale to elaborate all data, optimizing the time required for data processing.

In order to apply the regional vulnerability assessment methodology, all the data used to represent vulnerability factors and receptors in the case study area (Table 4) were first georeferenced with the same coordinate system, and then converted into raster (e.g. TIFF format). According to Preston et al. (2008) data were pre-processed based on their different initial format, as described below:

- data were conversed to a common spatial reference system (all data);

- raster data were resampled to $25 \mathrm{~m}$ resolution and the spatial extent was matched to that of the baseline grid (i.e. the DEM).

- Polygon data were converted to a $25 \mathrm{~m}$ resolution raster and the spatial extent was matched to the spatial extent of the base grid.

- Point data were used to interpolate a $25 \mathrm{~m}$ gridded surface using a spatial interpolation technique (e.g. nearest neighbour), using the spatial extent of the base grid.

As remarked also in Preston et al. (2008), heterogeneity of data, pre-processing and conversion processes introduced uncertainty into the indicators. Consequently, an adequate resolution of the resulting map should be selected in order to keep the error small.

With the aim to produce a qualitative ranking of vulnerability in the considered region visualized by means of relative vulnerability maps, all indicator data layers were assigned a vulnerability score and a weight, according to the procedure described in Sects. 3.2 and 3.3.
Vulnerability maps associated with each single vulnerability indicator were then aggregated according to the vulnerability functions described in Eqs. (1) and (2). The resulting vulnerability maps represent the bi-dimensional visualization and prioritization of vulnerable coastal units in relation to each single receptor $j$ and the specific impact $k$. The use of GIS gives the opportunity to interrogate the intermediate and final maps through simple or elaborated queries, to calculate several statistics and to perform hot spot analysis.

Vulnerability statistics are useful to synthesize information coming from vulnerability maps and communicate the results of the analysis to stakeholders and decision makers. Relevant statistics include the analysis of receptor surface and percentage that is associated with each vulnerability class in relation to each impact. Specific statistics can also be calculated in relation to other geographical/administrative units of interest (e.g. coastal municipalities or provinces and river basins).

The hot spot analysis allows the calculation of the GiZ score (Mitchell, 2005) in order to identify statistically significant hot spots (i.e. clusters of cells with high vulnerability values) and cold spots (i.e. clusters of cells with low vulnerability values). The GiZ score is therefore used to identify where cells with either high or low vulnerability values cluster spatially. The GIS tool implementing the GiZ score works by looking at each cell within the context of neighbouring cells. A cell with a high vulnerability value is interesting, but may not be a statistically significant hot spot. To be a statistically significant hot spot, a cell should have a high vulnerability value and be surrounded by other cells with high vulnerability values as well. The local sum for a cell and its neighbours is compared proportionally to the sum of all cells; when the local sum is much different than the expected local sum, and that difference is too large to be the result of random chance, a statistically significant GiZ score results (Mitchell, 2005).

Statistically significant positive GiZ scores (i.e. GiZ $>+1.96$ ) identify clusters of high vulnerability values (i.e. hot spot). The larger the GiZ score is, the more intense is the clustering of cells with high vulnerable values. GiZ scores ranging from -1.96 to +1.96 identify a general absence of clusters. Statistically significant negative GiZ scores (i.e. GiZ $<-1.96$ ) identify clusters with low vulnerability values (i.e. cold spot). The smaller the GiZ score is, the more intense is the clustering of cold spots.

The maps, the statistics and the results of the hot spot analysis obtained for the assessment of coastal vulnerability to sea level rise, storm surge flooding and coastal erosion in the North Adriatic region are described and discussed in Sect. 4.

\section{Results and discussion}

As described in Sect. 3.6, the results of the analysis include the construction of relative vulnerability maps, the elaboration of a hot spot analysis and the estimate of vulnerability 

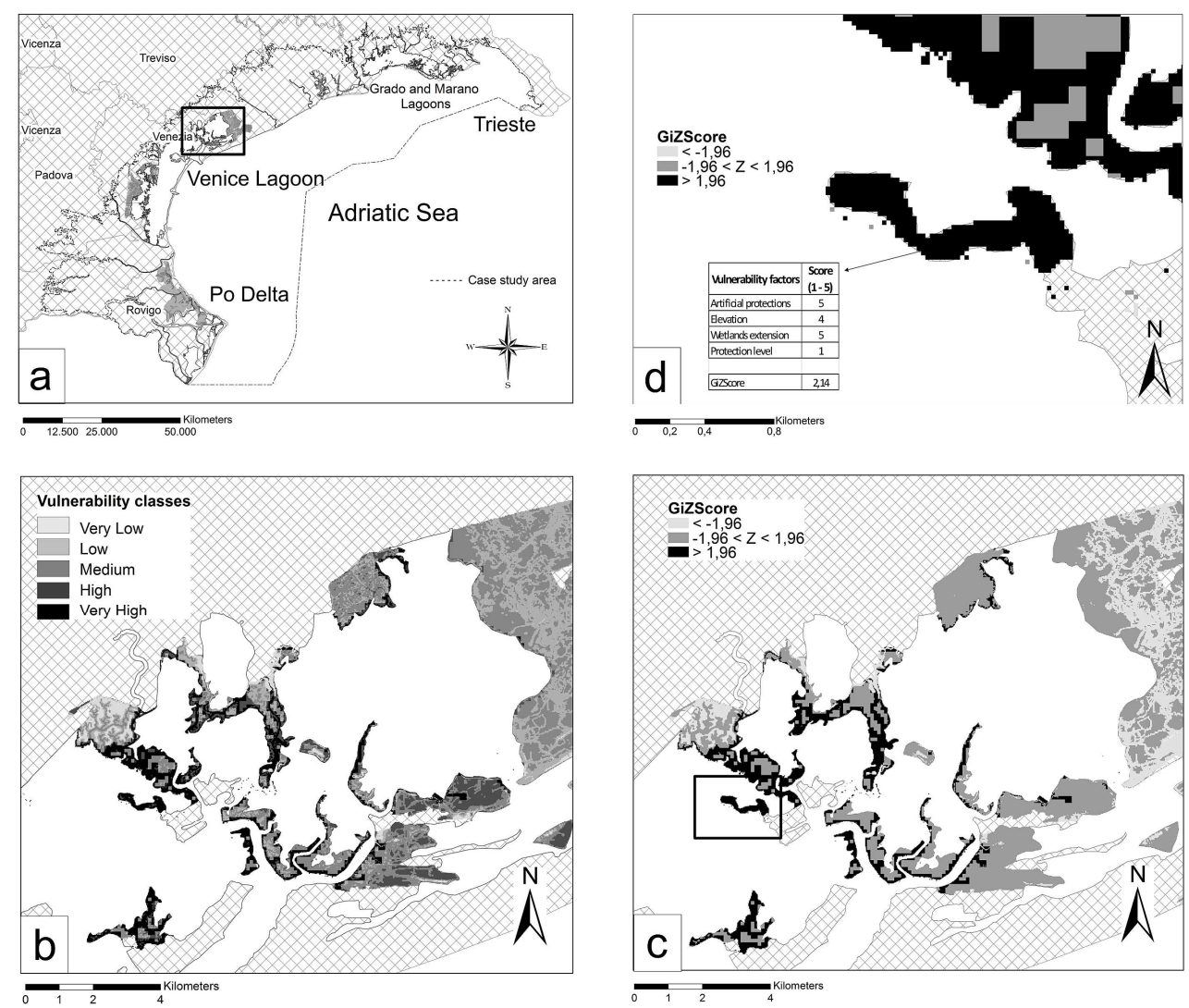

Fig. 3. Vulnerability map for the wetland receptor to the sea level rise inundation impact on the North Adriatic coast (a) and in the northern Venetian Lagoon (b). Maps representing the hot spots analyzed in the northern Venetian Lagoon (c) and a detailed hot spot with its contributing vulnerability scores (d).

statistics for multiple coastal receptors (i.e. beaches, river mouths, wetlands, terrestrial biological systems, protected areas, urban and agricultural areas) in relation to each climate-related impact (i.e. sea level rise inundation, storm surge flooding and coastal erosion).

The relative vulnerability maps allow the bi-dimensional visualization of receptor vulnerability to each analyzed impact and permit the identification of the dominant factors (i.e. pathway, susceptibility or value factors), determining the final vulnerability value. The hot spot analysis permits the verification of the statistically significant hot spots in the considered region. Vulnerability statistics support the prioritization of receptors and the quantification of sub-areas that are more vulnerable to potential climate change impacts in the same region.

The application of the proposed regional vulnerability assessment methodology to the North Adriatic case allowed to produce 25 maps, representing the vulnerability $\left(V_{j, k}\right)$ associated with each single receptor $j$ in relation to the impact $k$. In the following paragraphs, vulnerability maps, hot spots and statistics obtained for each analyzed impact and for representative coastal receptors will be described and discussed in more detail.

\subsection{Sea level rise inundation impact}

The application of the regional vulnerability assessment methodology and in particular of the Eq. (1) and (2) proposed in Sect. 3 allowed to calculate the vulnerability of all the receptors selected in the case study area (Table 3 ) to the sea level rise inundation impact.

A total amount of seven maps representing the vulnerability of each receptor to sea level rise inundation was produced.

For each map the hot spot analysis was performed by calculating the GiZ score (Sect. 3.6). Furthermore, vulnerability statistics were calculated in order to evaluate the distribution of vulnerability classes to the sea level rise inundation impact for each analyzed receptor.

An example of vulnerability and hot spots maps produced for the analysis of wetland vulnerability to sea level rise is reported in Fig. 3. Wetlands are mostly located in the lagoons of Venice, Grado and Marano, and in the Po River Delta (Fig. 3a). The use of GIS functions allows to focus on particular sub-areas (Fig. 3b) and to explore the spatial distribution of statistically significant hot spots (i.e. cells with high positive GiZ score values >1.96) (Fig. 3c, d). As shown in Fig. 3d, for each hot spot it is possible to query the system 


\begin{tabular}{|l|r|r|r|r|r|r|r|}
\cline { 2 - 8 } \multicolumn{1}{c|}{} & \multicolumn{9}{c|}{ Receptors $\left(\mathrm{km}^{2}\right)$} \\
\hline & Wetlands & Beaches & $\begin{array}{c}\text { Protected } \\
\text { areas }\end{array}$ & River mouths & $\begin{array}{c}\text { Terrestrial } \\
\text { biological systems }\end{array}$ & Urban areas & $\begin{array}{c}\text { Agricultural } \\
\text { areas }\end{array}$ \\
\hline Very low & 6,51 & 1,07 & 50,44 & 26,03 & 1,02 & 20,06 & 148,73 \\
\hline Low & 115,69 & 2,17 & 99,62 & 182,75 & 2,02 & 33,05 & 191,96 \\
\hline Medium & 101,32 & 3,10 & 617,34 & 459,77 & 9,10 & 29,37 & 1243,04 \\
\hline High & 38,58 & 2,39 & 63,94 & 26,83 & 7,12 & 37,71 & 74,83 \\
\hline Very high & 22,17 & 0,68 & 48,61 & 20,69 & 0,30 & 2,52 & 1,97 \\
\hline Tot & 284,27 & 9,42 & 879,94 & 716,07 & 19,55 & 122,70 & 1660,52 \\
\hline
\end{tabular}

a)

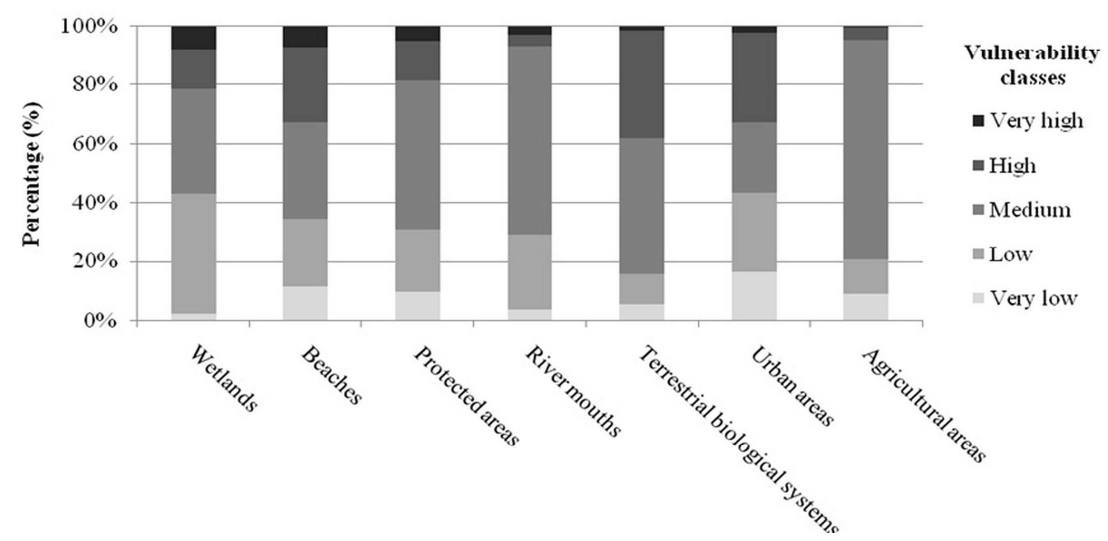

Fig. 4. Distribution of the territorial surface $\left(\mathrm{km}^{2}\right)$ (a) and of the percentage of surface (b) associated with each vulnerability class for the receptors located on the North Adriatic coast for the sea level rise inundation impact.

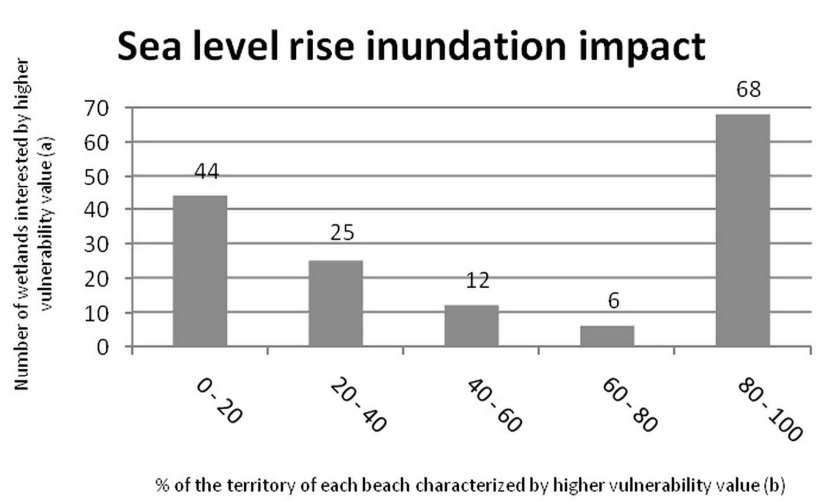

Fig. 5. Vulnerability of wetlands to the sea level rise inundation impact: number of wetlands affected by higher vulnerability values in the case study area (a), according to the percentage of the territory of each wetland characterized by higher vulnerability values (b).

in order to ascertain what are the main vulnerability factors that contributed in determining the final vulnerability value.

According to the overall results of the hot spot analysis, the majority of the wetland cells experience GiZ score values between -1.96 and 1.96. This means that there is a limited presence of clusters characterized by relatively high or low vulnerability values. Some hot spot areas with positive GiZ score values higher than 1.96 (i.e. statistically significant vulnerability hot spots) are concentrated in the northern part of the Venetian Lagoon and in the Grado and Marano Lagoons.
Moreover, some hot spots are spread in the southern part of the Po River Delta.

As shown in Fig. 3d, hot spot vulnerable areas are mostly located at the boarder of each wetland (i.e. in the spatial units adjoining to the water). By investigating underlying vulnerability scores, it is possible to affirm that vulnerability hot spots mainly correspond to sub-areas of smaller wetlands (i.e. wetlands with lower extension), characterized by the absence of artificial protections against sea level rise (Fig. 3d).

Starting from vulnerability maps, several statistics were also calculated in order to communicate and synthesize information coming from spatial vulnerability assessment. Figure 4 shows the territorial surface of each receptor $\left(\mathrm{km}^{2}\right)$ and the percentage of its total surface (\%) associated with each vulnerability class related to the sea level rise inundation impact on the North Adriatic coast.

According to Fig. 4b, wetlands, beaches and protected areas are affected by the highest percentages of the territory associated with very high vulnerability classes (i.e. from 5 to $8 \%$ ); these three receptors gained also a relevant percentage of the territory in the high and medium vulnerability classes (i.e. from 49 to $64 \%$ ).

The other receptors (i.e. river mouths, terrestrial biological systems, urban areas and agricultural areas) are characterized by lower percentages of territory associated with very high vulnerability classes (i.e. from 0.12 and $3 \%$ ). However, as shown in Fig. 4b, terrestrial biological systems and urban areas are affected by a relevant percentage of territorial surface in the high vulnerability class (i.e. from 31 to $36 \%$ ) 

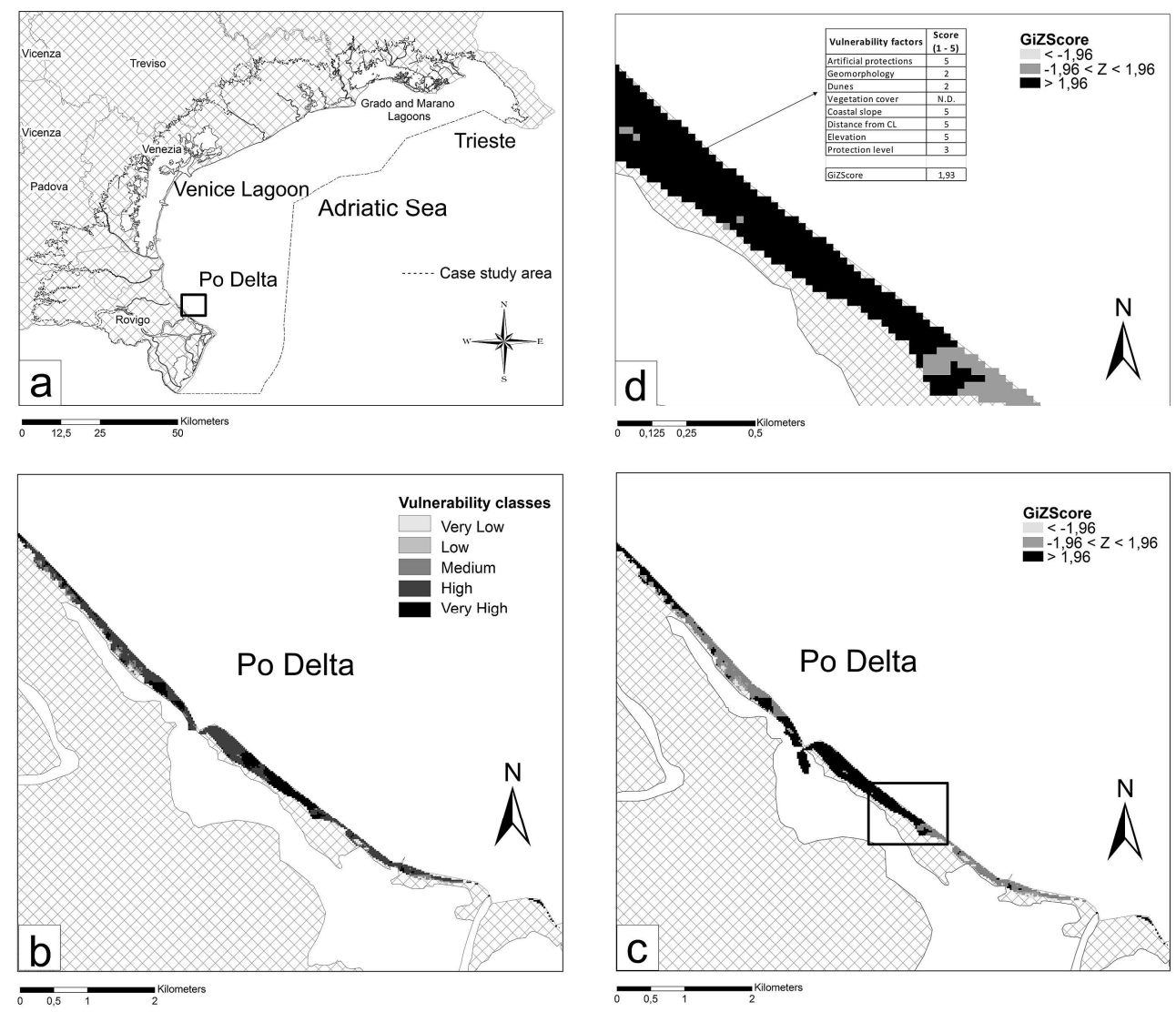

Fig. 6. Vulnerability map for the beach receptor to the storm surge flooding impact on the North Adriatic coast (a) and in a specific area of the Po River Delta (b). Maps representing the hot spots analyzed in the zoomed area of the Po River Delta (c) and a detailed hot spot with its contributing vulnerability scores (d).

compared to river mouths and agricultural areas that, on the contrary, gained very high percentage values in the medium vulnerability class (i.e. from 64 to $75 \%$ ).

Among the vulnerability factors contributing to determining higher vulnerability values to sea level rise inundation (Table 1a), the pathway factor "elevation" results to be the factor, which mainly contributed to determine the final vulnerability score. Accordingly, most vulnerable sub-areas are often characterized by low topography. Another important factor that mostly contributed in determining the final vulnerability score, particularly for shoreline receptors (i.e. wetlands and beaches), is the absence or presence of artificial protections, which was categorized in the susceptibility domain. In particular, the analysis of the distribution of artificial protections in the case study area allowed to identify vulnerable areas that lack measures of protection from sea level rise and may therefore require more extensive and urgent adaptation interventions. For what concerns the receptors with elevated percentage of territory associated with medium vulnerability class, in general, this is due to the fact that they gained medium vulnerability scores for the susceptibility and value vulnerability factors. Finally, a relevant percentage of wetlands (i.e. $40 \%$ ) is affected by a low vulnerability class because they generally have a large extension (i.e. value factor) that contributes in providing a low vulnerability score to the value vulnerability domain.

A specific statistic was also calculated for wetlands that were ranked as one of the receptors more vulnerable to sea level rise inundation in the case study area. The statistic was calculated starting from the vulnerability map presented in Fig. 3 and by means of specific spatial analysis GIS functions (e.g. layer intersection, zonal statistics).

First of all, it was possible to calculate the total amount of wetlands in the case study area (i.e. 375 ) and then evaluate the percentage of wetlands affected by cells with higher vulnerability values (i.e. $41 \%$ ). Afterwards, as shown in Fig. 5, the $41 \%$ of wetlands affected by higher vulnerability values (i.e. a total amount of 155 wetlands including cells belonging to the very high vulnerability class) were ranked based on the percentage of their total surface associated with the very high vulnerability class. From the analysis of the histogram reported in Fig. 5, it is possible to highlight that about $44 \%$ of the considered wetlands are characterized by high percentages of the territory (i.e. $80-100 \%$ ) associated with 


\begin{tabular}{|l|r|r|r|r|r|r|r|}
\cline { 2 - 8 } \multicolumn{1}{c|}{} & \multicolumn{9}{c|}{ Receptors $\left(\mathrm{km}^{2}\right)$} \\
\hline Class & Wetlands & Beaches & $\begin{array}{c}\text { Terrestrial } \\
\text { biological systems }\end{array}$ & $\begin{array}{c}\text { Protected } \\
\text { areas }\end{array}$ & Urban areas & $\begin{array}{c}\text { Agricultural } \\
\text { areas }\end{array}$ & River mouths \\
\hline Very low & 0,18 & 0,01 & 0,52 & 2,00 & 8,77 & 23,33 & 36,23 \\
\hline Low & 1,56 & 1,51 & 9,47 & 24,36 & 77,59 & 580,94 & 108,60 \\
\hline Medium & 139,93 & 2,71 & 11,60 & 744,18 & 109,67 & 1163,06 & 615,71 \\
\hline High & 76,87 & 7,09 & 15,55 & 131,08 & 57,08 & 405,02 & 27,34 \\
\hline Very high & 84,57 & 2,71 & 5,54 & 58,02 & 14,66 & 44,59 & 5,78 \\
\hline Tot & 303,10 & 14,02 & 42,69 & 959,64 & 267,77 & 2216,93 & 793,65 \\
\hline
\end{tabular}

$$
\text { a) }
$$

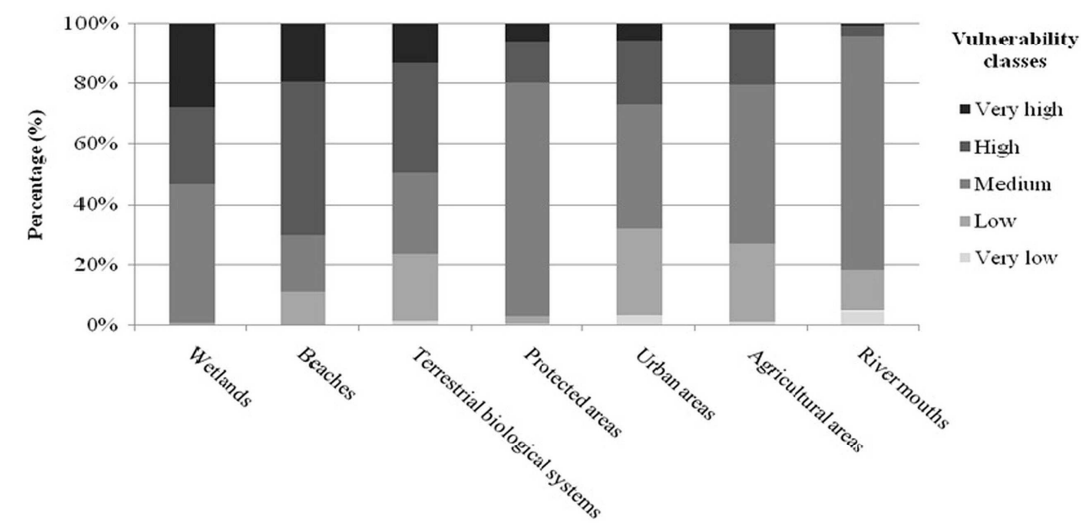

Fig. 7. Distribution of the territorial surface $\left(\mathrm{km}^{2}\right)$ (a) and of the percentage of surface (b) associated with each vulnerability class for the receptors located on the North Adriatic coast for the storm surge flooding impact.

\section{Storm surge flooding impact}

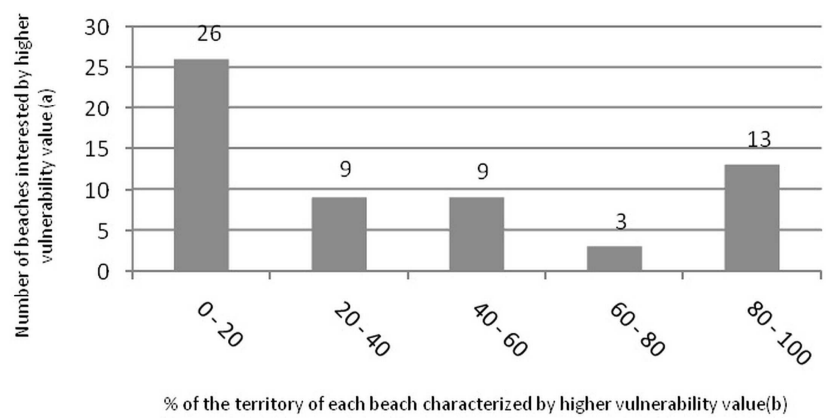

Fig. 8. Vulnerability of beaches to the storm surge flooding impact: number of beaches affected by higher vulnerability values in the case study area (a), according to the percentage of the territory of each beach characterized by higher vulnerability values (b).

higher vulnerability values in the case study area. This can be a useful statistic to give an idea about the relevance of the potential consequences of sea level rise inundation impact on this receptor.

\subsection{Storm surge flooding impact}

Considering that the northern part of the Adriatic Sea showed the higher maxima extreme sea levels (i.e. up to $200 \mathrm{~cm}$ ) compared to the rest of the eastern Mediterranean Basin (Tsimplis and Shaw, 2010), the regional vulnerability assessment methodology described in Sect. 3 was also applied for the assessment of coastal vulnerability to the impact storm surge flooding. In this case, a total amount of seven vulnerability maps of storm surge flooding was produced, one for each analyzed receptor (Table $1 b$ ).

The maps shown in Fig. 6 represent some pictures related to the vulnerability assessment (Fig. 6b) and to the hot spots analysis (Fig. 6c and d) of beaches of storm surge flooding. Beaches in the case study area are spread from the Timavo River mouth (municipality of Trieste, Friuli) to the Po River Delta in Veneto. Accordingly, there is the need to zoom the map in order to see the spatial distribution of vulnerability classes in the study area (Fig. 6b).

The results of the hot spot analysis showed a general predominance of GiZ score values in the medium class (i.e. from -1.96 to 1.96 ), representing a general absence of clusters. However, a concentration of relatively high vulnerable areas (i.e. clusters with GiZscore > 1.96) was observed in the Po River Delta area (Fig. 6c) and in the straight littoral zone between the Venetian and the Grado-Marano Lagoons. As shown in Fig. 6d, hot spots are generally characterized by proximity to the coastline, absence of artificial protections, scarcity of vegetation or presence of grassland and meadow, very low coastal slope and elevation, and medium or high environmental value.

Information coming from spatial vulnerability assessment is resumed in Fig. 7, which shows the territorial surface $\left(\mathrm{km}^{2}\right)$ and the percentage of the total surface of each receptor (\%) that is associated with each vulnerability class related to the storm surge flooding on the North Adriatic coast. 

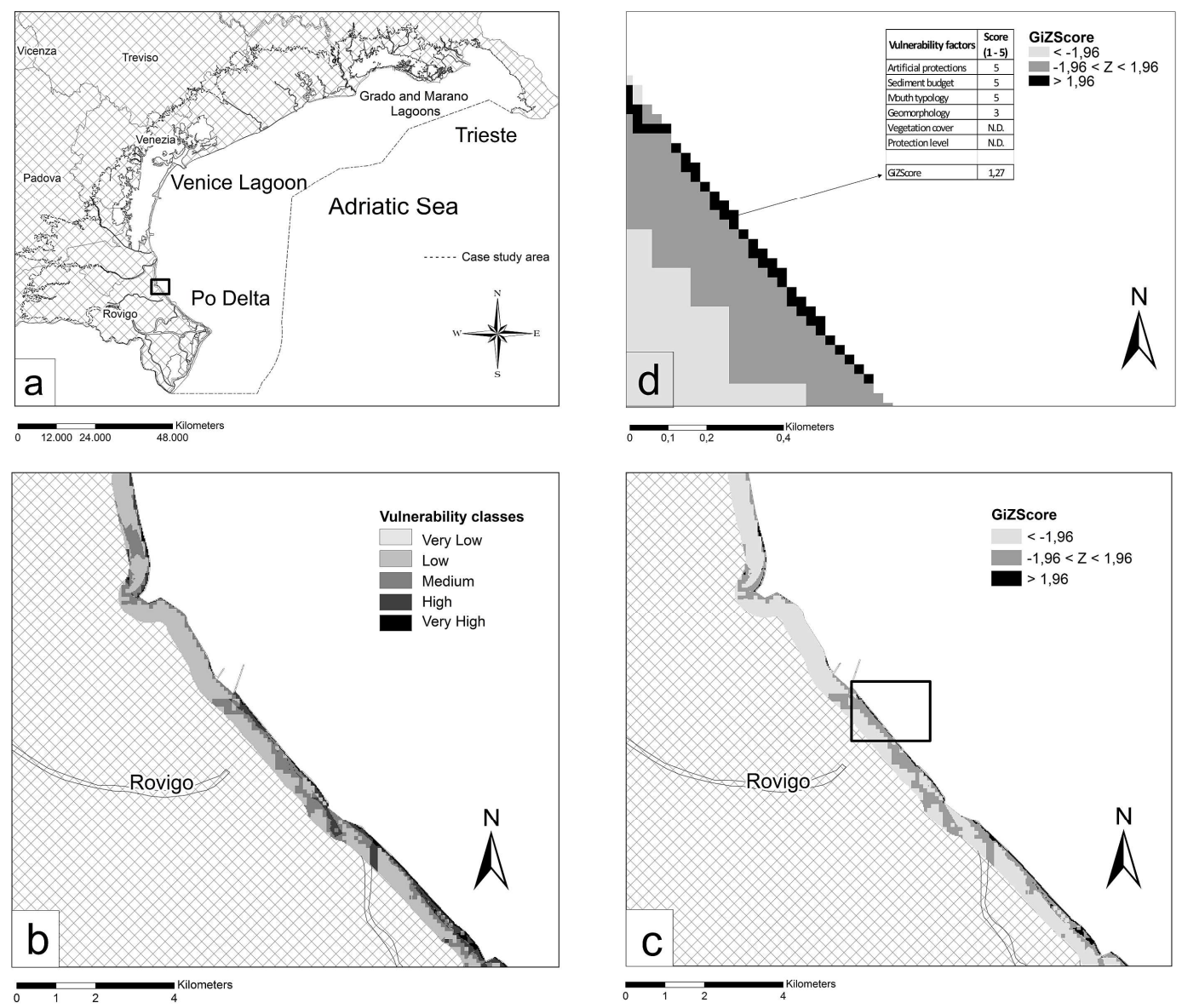

Fig. 9. Vulnerability map for the river mouth receptor related to the coastal erosion impact on the North Adriatic coast (a) and in a specific area of the Po River Delta (b). Maps representing the hot spots analyzed in the zoomed area of the Po River Delta (c) and a detailed hot spot with its contributing vulnerability scores $(\mathbf{d})$.

As shown in Fig. 7b, wetlands, beaches and terrestrial biological systems are the receptors most affected by very high and high vulnerability classes, with percentage values ranging from 53 to $70 \%$. Protected, urban, agricultural areas and river mouths follow in the ranking with lower high and very high vulnerable percentages ranging between 4 and $27 \%$. These receptors are instead characterized by relevant percentages of the territory in the medium vulnerability class (i.e. from 19.3 to $78 \%$ ).

Among the vulnerability factors selected to analyze coastal vulnerability to storm surge flooding (Table $1 b$ ), the pathway factors, elevation and distance from coastline, were very relevant in determining the final vulnerability values. Consequently, receptor units near the shoreline characterized by low elevation are often characterized by high vulnerability values. Other susceptibility factors that mainly contributed in determining the final vulnerability ranking are the presence or absence of artificial and natural protections (e.g. dams and dunes) and the coastal slope parameter. In particular, the localization of receptor units with low coastal slope or without natural or artificial protection could be relevant in order to identify areas where adaptation actions (e.g. beach nourishment, dune reconstruction or dike construction) should be more urgent.

A specific statistic was also calculated applying specific spatial analysis GIS functions (e.g. layer intersection, zonal statistics) to the 90 beaches that were identified in the case study area. As shown in Fig. 8, a total amount of 64 beaches (i.e. the $70 \%$ ) are affected by very high vulnerability values. In more detail, as shown in the histogram, 13/64 beaches (i.e. the $20 \%$ ) are characterized by high percentages of their territory (i.e. from 80 to $100 \%$ ), associated with very high vulnerability class and may need priority of intervention.

\subsection{Coastal erosion impact}

Considering that at international level the radius of influence of coastal erosion (RICE area) is represented by a buffer of $500 \mathrm{~m}$ from the coastline (EC, 2004), the methodology described in Sect. 3 for the assessment of vulnerability to 


\begin{tabular}{|l|r|r|r|r|}
\cline { 2 - 6 } \multicolumn{1}{c|}{} & \multicolumn{4}{c|}{ Receptors $\left(\mathrm{km}^{2}\right)$} \\
\hline Class & Wetlands & $\begin{array}{c}\text { Protected } \\
\text { areas }\end{array}$ & Beaches & $\begin{array}{c}\text { River } \\
\text { mouths }\end{array}$ \\
\hline Very low & 2,10 & 10,72 & 0,49 & 0,27 \\
\hline Low & 2,60 & 11,04 & 4,70 & 18,04 \\
\hline Medium & 3,96 & 6,45 & 4,32 & 6,65 \\
\hline High & 1,79 & 5,77 & 4,14 & 4,57 \\
\hline Very high & 1,38 & 2,49 & 0,65 & 1,23 \\
\hline Tot & 11,84 & 36,48 & 14,30 & 30,76 \\
\hline
\end{tabular}

a)

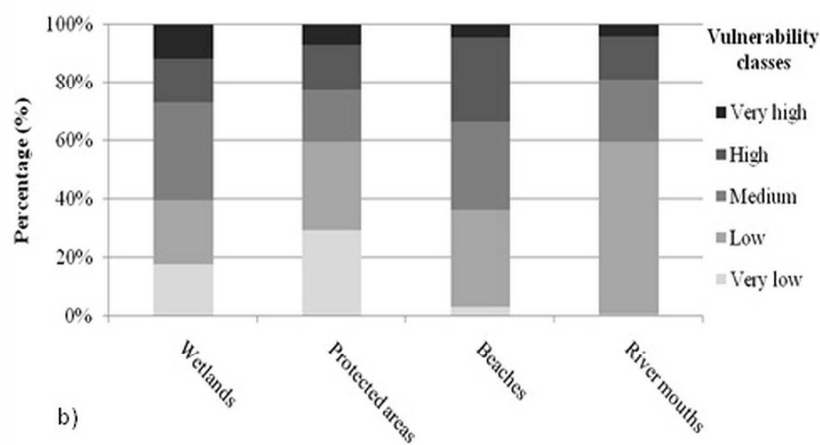

Fig. 10. Distribution of the territorial surface $\left(\mathrm{km}^{2}\right)$ (a) and of the percentage of surface (b) associated with each vulnerability class for the receptors located on the North Adriatic coast for the coastal erosion impact.

coastal erosion was applied to the coastal receptors located within $500 \mathrm{~m}$ from the North Adriatic shoreline (Fig. 9).

For this impact four maps were produced, one for each receptor that was considered as potentially vulnerable to coastal erosion (Table 1c).

The maps shown in Fig. 9 illustrate the main results obtained for the vulnerability assessment of river mouths to coastal erosion (Fig. 9b) and for the related hot spot analysis (Fig. 9c and d).

In the case study area, the receptor river mouth is basically represented by the Po River Delta, which is analyzed in more detail in Fig. 9 b.

The overall results attained for the area of the Po River Delta highlighted a predominant presence of cells with GiZ score values ranging from -1.65 to +1.65 or with low GiZ score values (i.e. $<-1.65$ ). This situation is representative of a general absence of clusters and of a presence of some cold spots. Medium to high GiZ score values (i.e. $>+1.96$ ) were uniformly spread in the Po Delta area in some locations along the coastline, and generally represent eroding sub areas characterized by the absence of artificial protections, scarcity of vegetation cover or presence of grasslands and meadows, and geomorphological attributes more vulnerable to coastal erosion (e.g. presence of sandy or muddy coast).

Moreover, Fig. 10 represents the territorial surface $\left(\mathrm{km}^{2}\right)$ and the percentage of territory of each vulnerable receptor that is associated with each vulnerability class in relation to the coastal erosion impact.

According to the ranking shown in Fig. 10b, beaches and wetlands are the receptors most affected by very high and high vulnerability classes, with percentage values ranging from $34 \%$ to $27 \%$, respectively. Protected areas and river mouths are characterized by a percentage of territory ranging from 23 to $19 \%$ within the very high and high vulnerability classes. Considering the medium vulnerability class, the percentage of the four receptors varies from $18 \%$ to $34 \%$.

For the coastal erosion impact, the final vulnerability scores are mainly due to the susceptibility factor of artificial and natural protections. These factors allow to distinguish areas that are more vulnerable to potential coastal erosion (i.e. areas without dams and dunes) from areas where the impacts associated with coastal erosion can be attenuated by the presence of natural or artificial protections. Another relevant factor for the assessment of receptor vulnerability to this impact is the sediment budget, which contributes in determining higher vulnerability scores to shoreline segments characterized by eroding processes. Finally, higher vulnerable areas are often valuable environmental areas characterized by high scores for the value factor protection level.

A specific statistic was also calculated for the assessment of the vulnerability of coastal municipalities to the coastal erosion impact. As shown in Fig. 11, the vulnerability statistic represents the percentage of surface of each receptor (i.e. beaches, wetlands, protected areas and river mouths) that is affected by higher vulnerability values (i.e. very high and high vulnerability classes) in the RICE area of each municipality.

This statistic allows to make a ranking of coastal municipalities based on the presence of highly vulnerable receptors and to identify what are the more vulnerable receptors for each municipality (e.g. wetlands and protected areas for Ariano nel Polesine and Porto Tolle).

Moreover, from the histogram of Fig. 11, it is possible to evaluate what are the coastal municipalities affected by a higher number of vulnerable receptors. For instance, Ariano nel Polesine, Porto Tolle and Rosolina have four receptors with high percentages of areas belonging to the high and very high vulnerable class; the majority of municipalities are characterized by the presence of three receptors affected by higher vulnerability values (e.g. Porto Viro, Marano Lagunare, Eraclea, San Michele al Tagliamento, Grado and Jesolo); finally, Staranzano, San Canzian d'Isonzo, and Venezia e Chioggia have at least two receptors characterized by high and very high vulnerability classes. For what concerns the municipality of Venice, it can be noticed that the assessment done for the coastal erosion impact did not allow to consider the majority of wetlands located outside the RICE area, within the Venetian Lagoon and accordingly, the statistic related to vulnerable wetlands could be underestimated. 


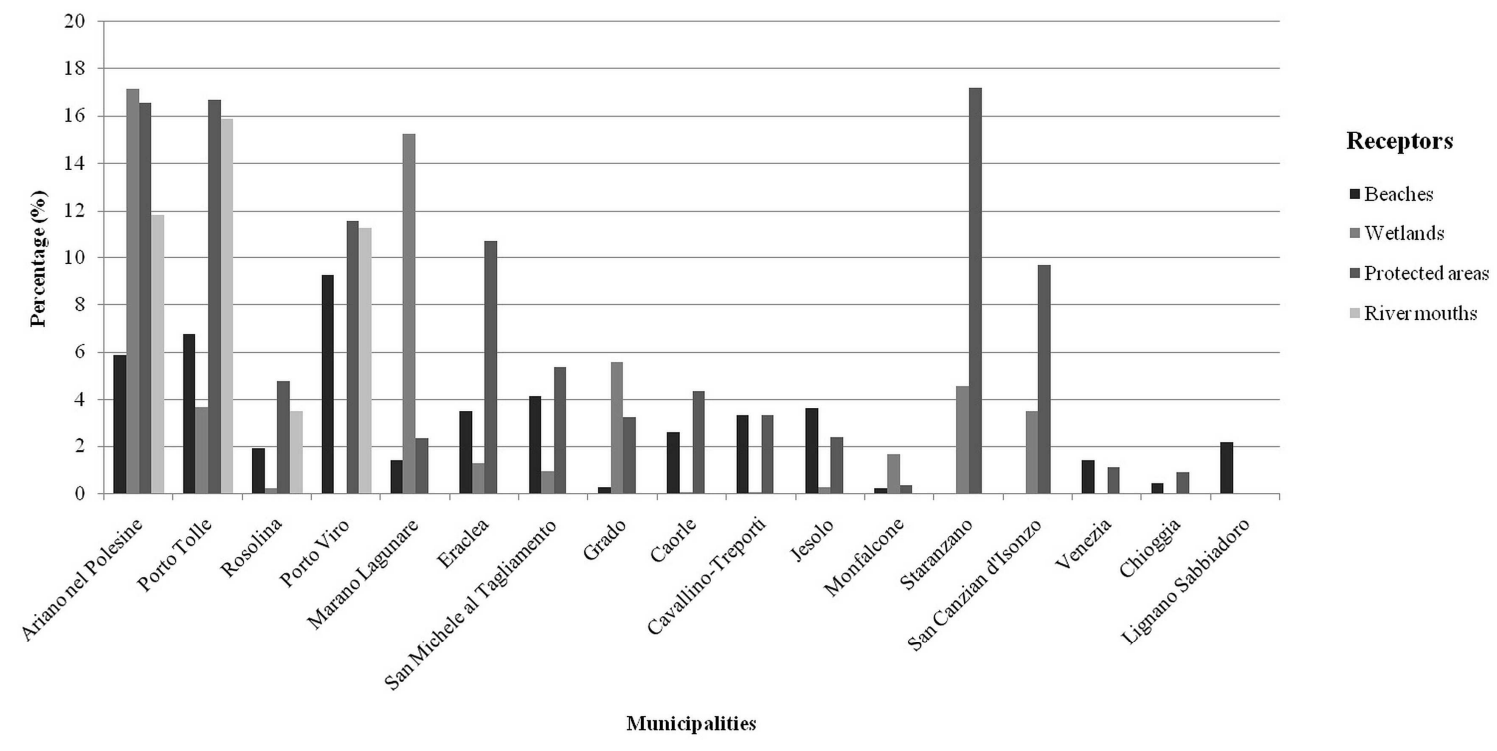

Fig. 11. Percentage of the surface of each receptor (i.e. beaches, wetlands, protected areas and river mouths) affected by higher vulnerability value (i.e. very high and high vulnerability classes) for the coastal erosion impact in each coastal municipality.

The histogram shown in Fig. 11 can therefore be useful to investigate what are the coastal municipalities that could require more attention in relation to the coastal erosion impact and to evaluate what are the receptors that may need more urgent adaptation measures to be protected from the adverse consequences of erosion (e.g. nourishment of beaches, construction of dikes).

\section{Conclusions}

The application of the regional vulnerability assessment methodology to the coastal area of the North Adriatic Sea led to a ranking of the relative vulnerability of each analysed receptor (i.e. beaches, river mouths, wetlands, terrestrial biological systems, protected areas, urban and agricultural areas) in relation to potential climate change impacts (i.e. sea level rise inundation, storm surge flooding and coastal erosion). The procedure proposed for the regional vulnerability assessment can effectively support decision makers in the spatial identification of the areas and targets characterized by different vulnerability levels and in the definition of management options useful to preserve the coastal receptors, which are potentially impacted by climate-related hazards at the regional scale.

The final vulnerability rankings are unitless numbers that judge the relative degree of receptor vulnerability to each analysed impact, in relation to qualitative vulnerability classes (i.e. very high, high, medium, low, very low). Consequently, higher vulnerability values do not imply high vulnerability in absolute terms, but only compared to other case study receptors and sub-areas for a given impact.
Moreover, it is important to highlight that the final vulnerability index is a summary number that aggregate scores coming from multiple heterogeneous parameters. The final decision-making process should therefore consider not only the final values of the index, but also the factors that contributed in determining that final vulnerability value (i.e. susceptibility, pathway or value factors). A correct interpretation of these factors is particularly relevant for the analysis of the potential adaptation measures that could be suitable for reducing the vulnerability of current hot spot areas.

For what concerns the accuracy of the results coming from the vulnerability assessment process, it should be considered that the proposed methodology adequately takes into account the best available geographical information at the regional scale, thus requiring a great effort to deal with a huge amount of data at a detailed spatial resolution. An important issue is therefore related to the collection and organization of data coming from different sources into homogeneous formats for the whole case study area. Finally, it was necessary to perform a huge pre-processing phase in order to manage data with different geographic coordinate systems, and to allow the GIS overlay and calculations. All these steps represent potential sources of uncertainty and of geometrical errors in the final vulnerability estimate.

Future improvements of the methodology can be obtained by eliciting more potential receptors and extending their subset of vulnerability factors. Moreover, the consistency of results provided by the methodology can be properly tested through a sensitivity analysis that allows to ascertain how much the output of the assessment could be influenced by its input parameters (i.e. scores and weights). 
Finally, the proposed methodology represents an useful tool for stakeholders and decision-makers in order to consider climate change-related issues in the coastal territory and develop sustainable integrated coastal zone management (ICZM) strategies.

Acknowledgements. The authors gratefully acknowledge the Centro Euro-Mediterraneo per i Cambiamenti Climatici (CMCC, www.cmcc.it) for financial support. The authors also thank their colleagues Valentina Gallina and Alex Zabeo for continuing support and discussion around the applied methodology and the results of the paper. A special thanks is also expressed to Enrico Alberighi, Francesco Rianna and Paolo Riccato for the technical assistance with the GIS application.

Edited by: F. J. Mendez

Reviewed by: S. Leschka and P. Fraile-Jurado

\section{References}

Abuodha, P. A. O. and Woodroffe, C. D.: Assessing vulnerability of coast to climate change: a review of approaches and their application to the Australian coast. University of Wollongong, Faculty of Science Papers, Research Online, 2006.

ARC: Technical Publication No. 130. Coastal Erosion Management Manual., 2000.

Australian Government: Climate Change Risks to Australia's Coast. A first pass national assessment, ISBN: 978-1-921298-71-4, 2009.

Bondesan, A., Castiglioni, G. B., Elmi, C., Gabbianelli, G., Marocco, R., Pirazzoli, P. A., and Tomasin, A.: Coastal areas at risk from storm surges and sea-level rise in northeastern Italy, J. Coastal Res., 11, 1354-1379, 1995.

Carbognin, L., Teatini, P., Tomasin, A., and Tosi, L.: Global change and relative sea level rise at Venice: what impact in term of flooding, Clim Dynam., 35, 1039-1047, doi:10.1007/s00382009-0617-5, 2009.

Colin, R. T., Evans, E. P., and Penning-Rowsell, E. C.: Future flooding and coastal erosion risks. Thomas Telford Publishing, Thomas Telford Ltd. ISBN: 978-0-7277-3449-5, 256 pp., 2007.

Cutter, S. L., Barnes, L., Berry, M., Burton, C., Evans, E., Tate, J., and Webb, J.: A place-based model for understanding community resilience to natural disasters, Glob. Environ. Chang., 18, 598-606, 2008.

Day, J. W., Are, D., Rismondo, A., Scarton, F., and Cecconi, G.: Relative sea level rise and Venice lagoon wetlands, in Active protection and water flow restoration of the Venice lagoon, Monographic Supplement to the Quaderni Trimestrali, 24-34, 1996.

EC: Living with coastal erosion in Europe: Sediment and Space for Sustainability, PART III - Methodology for assessing regional indicators, 2004.

EC: Climate Change and the European Water Dimension A Report to the European Water Directors. EU Report No. 21553., European Commission-Joint Research Centre (Publisher), Ispra, Italy, 2005.

EEA: The changing faces of Europe's coastal areas. EEA Report No 6/2006. European Environment Agency, Copenhagen, available at: www.eea.europa.eu/publications/eea_report_2006_6, 2006.
EEA: The European environment - state and outlook 2010, European Environment Agency, Copenhagen, 2010.

EU: Living with coastal erosion in Europe: Sediment and Space for Sustainability. PART III - Methodology for assessing regional indicators, 2004.

Engelen, G., Uljee, I., and White, R.: Report \& SIMLUCIA User Manual Report to UNEP CAR/RCU United Nations Environment Programme Caribbean Regional Co-ordinating Unit, Kingston, Jamaica, 1998.

Ferla, M., Cordella, M., Michielli, L., and Rusconi, A.: Long term variations on sea level and tidal regime in the lagoon of Venice, Estuar. Coast. Shelf. Sci., 75, 214-222, 2007.

Fontolan, G.: Risk of flooding: forecast and prevention plan, Province of Venice, Soil and Civil Defence Unit, Trieste, 92 pp., 2001.

French, P. W.: Coastal defences: processes, problems \& solutions, Florence, KY, USA, Routledge, available at: http://site.ebrary. com/, 2001.

Füssel, H. M. and Klein, R. J. T.: Assessing Vulnerability and Adaptation to Climate Change: An Evolution of Conceptual thinking. Paper presented at the UNDP Expert Group Meeting on "Integrating Disaster Reduction and Adaptation to Climate Change", Havana, Cuba, 17-19 June, 2002.

Füssel, H. M. and Klein, R. J. T.: Climate change vulnerability assessments: an evolution of conceptual thinking, Climatic Change, 75, 301-329, 2006.

Gambolati, G. and Teatini, P.: GIS Simulations of the Inundation Risk in the Coastal Lowlands of the Northern Adriatic Sea, Mathematical and Computer Modelling, 35, 963-972, 2002.

Giove, S., Brancia, A., Satterstrom, F. K., and Linkov, I.: Decision Support Systems and Environment: Role of MCDA, edited by: Marcomini A., Suter G. W., and Critto A., Decision Support Systems for Risk-Based Management of Contaminated Sites, Springer Science Business Media, LLC 2009, 53-73, 2009.

Gonella, M., Teatini, P., Tomasi, L., and Gambolati, G.: Flood risk analysis in the Upper Adriatic Sea due to storm surge, tide, waves, and natural and anthropic land subsidence, in: CENASCoastline Evolution of the upper Adriatic Sea due to Sea Level Rise and Natural and Anthropogenic Land Subsidence, edited by: Gambolati, G., Kluver Academic Publisher Dordrecht, the Netherlands, 313-324, 1998.

Gornitz, V. M.: Vulnerability of the East Coast, USA to future sea level rise, J. Coast. Res., 9, 201-237, 1990.

Gornitz, V. M.: Global coastal hazards from future sea level rise. Palaeogeography, Palaeoclimatology, Palaeoecology (Global and Planetary Change Section), 89, 379-398, 1991.

Gornitz, V. M., Daniels, R. C., White, T. W., and Birdwell, K. R.: The development of a coastal risk assessment database: vulnerability to sea-level rise in the U.S. Southeast, U.S. Government Report, Oak Ridge National Laboratory Tennessee, DE-AC0584OR21400, 1993.

Gutierrez, B. T., Williams, S. J., and Thieler, E. R.: Basic approach for shoreline change projections, in: Coastal Sensitivity to Sea-Level Rise: A Focus on the Mid- Atlantic Region, edited by: Titus, J. G. (coordinating lead author), Anderson, K. E., Cahoon, D. R., Gesch, D. B., Gill, S. K., Gutierrez, B. T., Thieler, E. R., and Williams S. J. (lead authors), A report by the U.S. Climate Change Science Program and the Subcommittee on Global Change Research. U.S. Environ- 
mental Protection Agency, Washington DC, 239-242, available at: http://www.epa.gov/climatechange/effects/coastal/pdfs/SAP 41_SynthesisandAssessmentProduct.pdf, 2009.

Henrotte, J.: Implementation, validation and evaluation of a Quasi3D model in Delft3D. M.Sc. thesis at Delft, University of Technology, Faculty of Civil Engineering and Geosciences, section of Hydraulic Engineering, 119 pp., 2008.

Hinkel, J.: DIVA: an iterative method for building modular integrated models, Adv. Geosci., 4, 45-50, 2005,

http://www.adv-geosci.net/4/45/2005/.

Hinkel, J. and Klein, R.: Integrating knowledge for assessing coastal vulnerability to climate change, in: Managing Coastal Vulnerability: An Integrated Approach, edited by: McFadden, I., Nicholls, R. J., and Penning-Rowsell, E. C., 2007, Elsevier Science, Amsterdam, The Netherlands, 2007.

Hinkel, J., Nicholls, R., Vafeidis, A., Tol, R., and Avagianou, T.: Assessing risk of and adaptation to sea level rise in the European Union: an application of DIVA, Mitigation and Adaptation Strategies for Global Change, 15, 703-719, doi:10.1007/s11027010-9237-y, 2010.

Hsu, Y. L., Dykes, J. D., Allard, R. A., and Kaihatu, J. M.: Evaluation of Delft3D Performance in nearshore flows. Naval Research Laboratory, NRL/MR/7320-06-8984, 2006.

IPCC: Climate Change 2007: Impacts, Adaptation and Vulnerability. Summary for Policymakers. Contribution of Working Group II to the Fourth Assessment Report of the Intergovernmental Panel on Climate Change, Geneva, 2007a.

IPCC: Climate Change 2007: The Physical Science Basis. Summary for Policymakers Contribution of Working Group I to the Fourth Assessment Report of the Intergovernmental Panel on Climate Change, Geneva, 2007b.

IPCC: Climate change and water, Technical Paper VI, IPCC Secretariat, Geneva, 2008.

Kenny, G. J., Warrick, R. A., Campbell, B. D., Sims, G. C., Camilleri, M., Jamieson, P. D., Mitchell, N. D., McPherson, H. G., and Salinger, M. J.: Investigating climate change impacts and thresholds: an application of the CLIMPACTS integrated assessment model for New Zealand agriculture, Climatic Change, 46, 91$113,2000$.

Kienberger, S., Lang, S., and Zeil, P.: Spatial vulnerability units expert-based spatial modelling of socio-economic vulnerability in the Salzach catchment, Austria, Nat. Hazards Earth Syst. Sci., 9, 767-778, doi:10.5194/nhess-9-767-2009, 2009.

Kiker, G. A., Bridges, T. S., Varghese, A., Seager, T. P., and Linkov, I.: Application of Multicriteria Decision Analysis in Environmental Decision Making, Integrated Environmental Assessment and Management, 1, 95-108, 2005.

Klein, R. J. T., Nicholls, R. J., and Thomall, F.: Resilience to natural hazards: How useful is this concept?, Environmental Hazards, 5, 35-45, 2003.

Lambeck, K., Antonioli, F., Anzidei, M., Ferranti, L., Leoni, G., Scicchitano, G., and Silenzi, S.: Sea level change along the Italian coast during the Holocene and projections for the future, Quaternary International, 232, 250-257, 2011.

Lionello, P., Cogo, S., Galati, M. B., and Sanna, A.: The Mediterranean surface wave climate inferred from future scenario simulations, Global Planet. Change, 63, 152-162, 2008.

Malczewski, J.: GIS-based multicriteria decision analysis: A survey of the literature, International Journal of Geographical Informa- tion Science, 20, 249-268, 2006.

McLaughlin, S. and Cooper, J. A. G.: A multi-scale coastal vulnerability index: A tool for coastal managers?, Environmental Hazards, 9, 233-248, 2010.

McLeod, E., Poulter, B., Hinkel, J., Reyes, E., and Slam, R.: Sealevel rise impact models and environmental conservation: a review of models and their application, Ocean \& Coastal Management, 53, 507-517, 2010.

Ministry of Environment: Fifth National Communication under the UN Framework Convention on Climate Change, November, 2009.

Mitchell, A.: The ESRI Guide to GIS Analysis, Volume 2. ESRI Press, 2005.

Mocenni, C., Casini, M., Paoletti, S., Giordani, G., Viaroli, P., and Zaldìvar Comenges, J.: A Decision Support System for the management of the Sacca di Goro (Italy), in: Decision Support Systems for Risk-Based Management of Contaminated Sites, edited by: Marcomini A., Suter II G. W., and Critto, A., Springer, 399422, 2009.

Mokrech, M., Hanson, S., Nicholls, R. J., Wolf, J., Walkden, M., Fontaine, C. M., Nicholson-Cole, S., Jude, S. R., Leake, J., Stansby, P., Watkinson, A. R., Rounsevell, M. D. A., Lowe, J. A., and Hall, J. W.: The Tyndall coastal simulator, Journal of Coastal Conservation, 15, 325-335, doi:10.1007/s11852-0090083-6, 2009.

Nicholls, R. J.: Coastal flooding and wetland loss in the 21 st century: changes under the SRES climate and socio-economic scenarios, Global Environmental Change, 14, 69-86, 2004.

Nicholls, R. J. and Cazenave, A.: Sea-Level Rise and Its Impact on Coastal Zones, Science, 328, 1517, doi:10.1126/science.1185782, 2010.

OECD: Development and climate change in Bangladesh: focus on coastal flooding and the sundarbans by Agrawala, S., Ota T., Ahmed A. U., Smith J. and van Aalst M. COM/ENV/EPOC/DCD/DAC(2003)3/FINAL, 2003.

Ozyurt, G., Ergin, A., and Esen, M.: Indicator based coastal vulnerability assessment model to sea level rise, in: The proceedings of the Seventh International Conference on Coastal and Port Engineering in Developing Countries COPEDEC VII "Best Practices in the Coastal Environment", 24-28 February 2008, Dubai, UAE, 2008.

Park, R. A., Clough, J. S., Jones, R., and Galbraith, H.: Modelling the impacts of sea-level rise. NOAA Proceedings of the XIII Biennial Coastal Zone Conference, Baltimore, USA, July, 2003.

Pfeffer, W. T., Harper, J. T., and O'Neel, S.: Kinematic Constraints on Glacier Contributions to 21st-Century Sea-Level Rise, Science, 321, 1340-1343, 2008.

Pirazzoli, P. A.: A review of possible eustatic, isostatic and tectonic contributions in eight late-Holocene relative sea-level histories from the Mediterranean area, Quaternary Sci. Rev., 24, 19892001, 2005.

Preston, B. L., Smith, T. F., Brooke, C., Gorddard, R., Measham, T. G., Withycombe, G., Mcinnes, K., Abbs, D., Beveridge, B., and Morrison, C.: Mapping Climate Change Vulnerability in the Sydney Coastal Councils Group, prepared for the Sydney Coastal Councils Group, 2008.

Rahmstorf, S.: A semi-empirical approach to projecting future sealevel rise, Science, 315, 368-370, 2007. 
Ramieri, E., Hartley, A., Barbanti, A., Duarte Santos, F., Gomes, A., Hilden, M., Laihonen, P., Marinova, N., and Santini, M.: Methods for assessing coastal vulnerability to climate change, European Topic Centre on Climate Change Impacts, Vulnerability and Adaptation (ETC CCA) Technical Paper, Bologna (IT) 93, October 2011.

Romieu, E., Welle, T., Schneiderbauer, S., Pelling, M., and Vinchon, C.: Vulnerability assessment within climate change and natural hazard contexts: revealing gaps and synergies through coastal applications, Sustainable Science, 5, 159-170, 2010.

Schirmer, M., Schuchardt, B., Hahn, B., Bakkenist, S., and Kraft, D.: KRIM: Climate change risk construct and coastal defenceDEKLM German climate research programme-proceedings, 269-273, 2003.

Seminara, G., Bolla Pittaluga, M., Tambroni, N., and Garotta, V.: Open problems in modelling the long-term morphodynamic evolution of the Venice Lagoon, in: Flooding and environmental challenges for Venice and its Lagoon: state of knowledge, edited by: Fletcher, C. A. and Spencer, T., Cambridge University Press, New York, 369-378, 2005.

Sharples, C.: Indicative mapping of Tasmanian Coastal vulnerability to climate change and sea level rise: explanatory report, 2nd edn. Department of Primary Industries, Water \& Environment, Tasmania, 112 pp., 2006.

Sharples, C., Mount, R., and Pedersen, T.: The Australian coastal smartline geomorphic and stability map version 1: manual and data dictionary, 2009.

Shuang-Ye, W., Najjar, R., and Siewert, J.: Potential impacts of sealevel rise on the Midand Upper-Atlantic Region of the United States, Climatic Change, 95, 121-138, 2009.

Simeoni, U. and Corbau, C.: A review of the Delta Po evolution (Italy) related to climatic changes and human impacts, Geomorphology, 107, 64-71, 2009.

Simeoni, U., Fontolan, G., Tessari, U., and Corbau, C.: Domains of spit evolution in the Goro area, Po Delta, Italy Geomorphology, 86, 332-348, 2007.

Tomasin, A. and Pirazzoli, P. A.: Extreme sea levels on the Adriatic coasts: a comparison of estimation methods, Atti dell'Istituto Veneto di Scienze, Lettere ed Arti Tomo CLXVII (2008-2009), 53-82, 2008.

Torresan, S., Critto, A., Dalla Valle, M., Harvey, N., and Marcomini, A.: Assessing coastal vulnerability to climate change: comparing segmentation at global and regional scales, Sustainable Science, 3, 45-65, doi:10.1007/s11625-008-0045-1, 2008.

Torresan, S., Critto, A., Tonino, M., Alberighi, E., Pizzol, L., Santoro, F., and Marcomini, A.: Climate change risk assessment for coastal management, in: Proceedings of the Ninth International Conference on the Mediterranean Coastal Environment, edited by: Özhan, E., 10-14 November 2009, Sochi, Russia, MEDCOAST, Middle East Technical University, Ankara, Turkey 91$102,2009$.
Travers, A., Elrick, C., and Kay, R.: Background Paper: Climate Change in Coastal Zones of the Mediterranean, Split, Priority Actions Programme, 2010.

Tsimplis, M. N. and Shaw, A. G. P.: Seasonal sea level extremes in the Mediterranean Sea and at the Atlantic European coasts, Nat. Hazards Earth Syst. Sci., 10, 1457-1475, doi:10.5194/nhess-101457-2010, 2010.

UKCIP: Climate adaptation: risk, uncertainty and decision-making, Robert Willows, edited by: Connell, R., 166 pp., 2003.

Umgiesser, G., Anderson, J. B., Artale, V., Breil, M., Gualdi, S., Lionello, P., Marinova, N., Orlić, M., Pirazzoli, P., Rahmstorf, S., Raicich, F., Rohling, E., Tomasin, A., Tsimplis, M., and Vellinga, P.: From Global to regional: Local Sea Level Rise Scenarios. Focus on the Mediterranean Sea and the Adriatic Sea. Workshop Report n.1, United Nations Educational Scientific and Cultural Organization (UNESCO), 25 pp., 2010.

UNEP MAP: ICZM Protocol in the Mediterranean, available at: www.pap-thecoastcentre.org/razno/PROTOCOL\%20ENG\% 20IN\%20FINAL\%20FORMAT.pdf, 2008.

UN-ISDR (United Nations International Strategy for Disaster Reduction): Terminology: Basic terms of disaster risk reduction, 2009.

Vermeer, M. and Rahmstorf, S.: Global sea level linked to global temperature, P. Natl. Acad. Sci., 106, 21527-21532, 2009.

Voice, M., Harvey, N., and Walsh, K.: Vulnerability to Climate Change of Australia's Coastal Zone: Analysis of gaps in methods, data and system thresholds, Australian Greenhouse Office, Department of the Environment and Heritage, 2006.

Wachenfeld, D., Johnson, J., Skeat, A., Kenchington, R., Marshall, P., and Innes, J.: Chapter 1 Introduction to the Great Barrier Reef and climate change, in: Climate Change and the Great Barrier Reef, edited by: Johnson, J. E. and Marshall, P. A., Great Barrier Reef Marine Park Authority and Australian Greenhouse Office, Australia, 2007.

Warrick, R. A.: Using SimCLIM for modelling the impacts of climate extremes in a changing climate: a preliminary case study of household water harvesting in Southeast Queensland, 18th World IMACS /MODSIM Congress, Cairns, Australia, July 2009, 2583-2589, 2009.

Warrick, R. A., Ye, W., Kouwenhoven, P., Hay, J. E., and Cheatham, C.: New developments of the SimCLIM model for simulating adaptation to risks arising from climate variability and change, International Congress on Modelling and Simulation, Modelling and Simulation Society of Australia and New Zealand, Melbourne, December 2005, 170-176, 2005.

Zald, A. E., Shelly, S., and Wade, T.: A to Z GIS: An Illustrated Dictionary of Geographic Information Systems. Articles (Libraries), Paper 144, 2006. 